\title{
The Effect of Overseas Educational Experience on Pro-Environmental Practices: Evidence from Cambodian Academic Scholars
}

\author{
Bandos Ros ${ }^{1,2}$ \\ ${ }^{1}$ Graduate School for International Development and Cooperation, Hiroshima University, Hiroshima, Japan \\ ${ }^{2}$ Department of Environmental Education, Ministry of Environment, Phnom Penh, Cambodia \\ Email: ros.bandos@gmail.com
}

How to cite this paper: Ros, B. (2021) The Effect of Overseas Educational Experience on Pro-Environmental Practices: Evidence from Cambodian Academic Scholars. Journal of Environmental Protection, 12, 824-854. https://doi.org/10.4236/jep.2021.1211049

Received: September 30, 2021

Accepted: November 12, 2021

Published: November 15, 2021

Copyright () 2021 by author(s) and Scientific Research Publishing Inc. This work is licensed under the Creative Commons Attribution International License (CC BY 4.0).

http://creativecommons.org/licenses/by/4.0/ (c) (i) Open Access

\begin{abstract}
This paper revealed that after spending years overseas for learning, Cambodian fellows realized that a clean society more likely results from the adopting of a waste management system. The lack of such is the main barrier for waste separation willingness and practices in Cambodia. Self-transcendence values and volunteerism are empirically found as the fundamental factors for any interventions designed to promote pro-environmental intentions and practices respectively. The fellows engaging in volunteerisms appear to do waste separation, ignoring how inconvenient the waste management system or facilities are. Similarly, the fellows concerning the environmental and social issues appear to spare their valuable time to do waste-separation which they find not difficult. This is not the case in this COVID-19 epidemic though. The study results imply that in a society where an inconvenient waste management system is in place the fellows without past volunteering, no matter how knowledgeable they are, will less likely engage in the waste-sorting practice.
\end{abstract}

\section{Keywords}

Pro-Environmental Practice, Self-Transcendence, Volunteerism, Instrumental Variable (IV)

\section{Introduction}

There has been increasing recognition that human activities have become so pervasive and profound in their consequences that they degrade the environment on a global scale [1]. As of 2015, approximately 6300 million tons of plastic waste had been generated by the continuing growth of the population [2], around 
$79 \%$ was accumulated in landfills or the natural environment. If not properly managed, the waste generated will be a serious health hazard and lead to the spread of infectious diseases [3]. Therefore, citizens as consumers need to be responsible for modifying their lifestyle for the sake of preserving global natural resources and of future generations through, activities that result in less or no harmful effects on humans and the environment.

Sound Materials-Cycles Society (SMC) known as the circular economy is an idea believed to reduce negative environmental impacts [4] and has been defined as an approach to sustainable development [5], a society where human beings shall be in harmony with nature [6]. Estimation of the movement of materials in an economic society is the concept underlying the SMC, particularly putting 3Rs (i.e., reduction, reuse and recycle) into action. This target is impossible till human being is motivated to adopt pro-environment behavior [7] which is determined by the combination of socio-economic and psychological determinants [8].

Education is, on one hand, one of the motivating factors influencing human's attitude toward the environment [9] [10]. People who are knowledgeable in environment can make better decisions about what and how they consume and dispose [11] [12] as cited by [13] [14] [15] [16] [17]. Procedural knowledge on recycling is, for instance, obviously important and identified as a predictor for attitude towards source-separated collection [18] and as a determinant for recycling behavior [11] [19]. Accessibility to convenient recycling facilities is, on the other hand, indeed a situational factor that can convince people to separate waste at source [20]-[25] and it is more effective than information [26]. Combining these two, know-how and accessibility to recycling, affects the relationship between people's attitudes and their recycling motives [27] [28] [29] [30].

The regular practice of an act such as separating waste under stable conditions is more likely to habituate the behavior [31] [32], becoming less dependent on intention [33]. As new behavior can be activated as soon as the first quarter of the year [34], the daily practice of waste separation at source among fellows experiencing overseas education will, it can be assumed, habituate waste separation. After which it becomes very hard to change the habit unless there is a contextual change that disrupts habitual behavior [34] [35] [36]. So, does overseas education transfer the knowledge and practice about waste recycling? Or does the contextual change really disrupt the habitual behavior?

Past recycling behavior is one of the determinants of intention [37] [38] and behavior toward recycling as well that providing residents convenient location of waste separation and collection facilities will have habitual behavior formed through repeated waste management practices. In empirical studies, past recycling behavior is identified as one of significant predictors of continuation of the practice [39] [40]. Some studies found that experiences with recycling influences motives to recycle and could even facilitate knowledge and attitude change [27] [41] [42]. As cited by [43], this statement is supported by three meta-analytic 
studies, citing that variance in intention is more explained upon the addition of past behavior into the model [44] [45]. So, does overseas education positively correlate with waste recycling intention? The intention is a predictor of behavior and is influenced by attitude, subjective norms, and perceived behavioral control [46].

Volunteering has been widely studied in developed countries and it has been found as the key determinant of pro-environmental practices and strongly affects waste management practices [47]. However, it seems there is a lack of studies of its relationship with pro-environmental practices in an inconvenient context, particularly in developing countries where waste recycling facilities are still conventional. Waste separation practice in an inconvenient context is a part of volunteering since it takes time and other resources (i.e., opportunity cost). Whether a person will more likely be recognized as a volunteer or not relies on the amount of work done (i.e., cost) [48]. Since past volunteering has a causal influence on current and future participation [49], does past volunteering more likely positively correlates with waste separation practice?

In addition to education and convenience, human values could drive a person's actions [50]. Human values and identity are factors crucial to motivating people to start recycling [51]. These two factors were found to influence pro-environmental attitudes and behavior [52] [53]. Although it's accepted that there is a value-action gap, it influences a broad range of behaviors [54]. A study suggested considering human values, altruism, and biosphere, as one of the factors in any programs designed to promote stable pro-environmental behavior [55]. Dominicis confirmed altruism has a relationship with pro-environmental behaviors [56] which is beyond the claims that values were just related to pro-environmental beliefs or attitudes [57] [58] [59] [60].

Some theories have been tested and confirmed the positive relationship between values and environmental behaviors. The Schwartz's Norm Activation Model (NAM) in 1977, originally developed for altruistic behavior -helping others [61], has been found to influence environment-oriented behaviors as well [62] [63] [64] [65]. Developed based on the altruism theory of Schwartz 1977 [66], Stern et al.'s Values Beliefs Norms (VBN) theory developed for pro-environmental behavior confirmed that an altruistic person is more likely to behave pro-environmentally [67]. Self-transcendence value, the combination between altruism and biosphere value [68] [69], makes individuals focus on the interests of others and the environment [50] [70] and is typically positively related to both pro-environmental beliefs and behaviors [69] [71] [72] [73] [74]. However, its relationship with waste-separation practice has unlikely been tested. So, whether Self-Transcendence value affects behavior toward waste separation is still a question.

This is a natural experimental study purposively designed to compare a group of people with educational background at local level (i.e., developing country where waste recycling facilities are conventional) with another group of people who experiences overseas education (i.e., developed countries where waste recy- 
cling facilities are in place) as a plus to find out whether there is statistically significant difference between their pro-environmental practices, intentions, and knowledge. The study explores how resilient the practices and intentions will be upon graduation and their return home, where facilities and accessibility to recycling are not yet in place. The remainder of the paper is organized as follows. Section I describes materials and methods used for analysis. Section II illustrates the results and discussion and finally, Section III is the conclusions.

\section{Material and Methods}

The study was conducted online using Survey Monkey. Two groups, the testing group and a control group were interviewed. In cooperation with the Cambodian Association in Japan (CSAJ) and the Hiroshima Alumni Network (HAN), the online survey was administered using the mailing list of the Association and Telegram Apps of the network to target the alumni, a group of people who had been educated overseas $(N=164)$. Around $85 \%$ of respondents gained their educational experiences in Japan. The remaining 15\% experienced overseas education in Thailand, New Zealand, Australia, South Korea, or the Netherlands.

To reach the group of people with only a local education in Cambodia $(N=$ $59)$, the questionnaires were distributed via social media, Facebook. Within two weeks, starting from mid-November 2020, a total of 224 respondents agreed and participated in the survey.

\subsection{Outcome Variables}

The two outcomes to be tested include pro-environmental behaviors and the environmental knowledge affecting people's motivations towards waste separation. Waste separation is explored as being a requisite for any campaigns to promote solid waste management in Cambodia [75]. As an indicator of behavior, respondents were asked about the frequency with which they had engaged in two types of waste management practices: 1) waste separation and 2) waste reduction. This is a single-item measure: "How often do you separate waste?" and "How often do you use your own reusable shopping bag?" The frequency of their waste disposal practice is then divided into five categories: never, rarely, sometimes, often, and always.

For environmental knowledge, respondents were asked to rate the 5-point $\mathrm{Li}$ kert scale on five items: 1) "People in my family don't support waste separation"; 2) "I will not segregate unless the waste collection service requires me to do so"; 3) "My neighboring families never separate their waste"; 4) "Waste separation is difficult" and 5) "I don't have time to separate waste". Participants responded on a 5 -point scale $(0=$ strongly disagree to $4=$ strongly agree $)$.

\subsection{Control Variables}

Participants reported their gender, age, and marital status; these three background variables were included in our subsequent analyses as control variables. 
A binary indicator ( 1 = volunteerism, $0=$ otherwise $)$ was also added as the covariate since it strongly affects waste management practices [47]. Since the survey took place during the outbreak of COVID-19 by which human physical and mental health is affected [76], it is crucial to some extent to understand its relationship with daily practice of waste management. So, respondents were asked to rate the 5-point Likert scale on one-item measure for one's own concerns over COVID-19: "How concerned are you about the possibility of becoming infected by COVID-19". Participants responded on a 5 -point scale $(0=$ not at all to $4=$ extremely concern). Higher scores indicate people are concerned about the possibility of a COVID-19 infection.

For social and environmental concerns, respondents were asked to rank the 7 -point Likert scale on nine-item measure $(0=$ extremely disagree to $6=\mathrm{ex}$ tremely agree). These items were adopted from a study conducted to measure human value in environment, self-transcendence [77] [78]. A row mean score of the construct was computed after the reliability and validity of the construct were measured. Higher scores indicate people are more likely altruistic and biospheric. Descriptive statistics of these outcomes and control variables can be found in SI Table B1.

To evaluate the construct reliability and validity, Alpha Reliability ( $\propto$ ), the internal reliability (rho) [79], the convergent validity of the indicators as well as the composite reliability of the construct [80] were all tested. These tests are used to find out if all indicators belonging to the same construct are highly correlated with each other. The internal reliability (rho) was computed based on the result of Confirmatory Factor Analysis (CFA) analyzed with Stata 15.1.

The CFA results show the goodness of fit with the data set. All the factor loadings are substantial and statistically significant. If you are 1 standard deviation higher on self-transcendence, you will respond 0.90 standard deviations higher on X1 (i.e., it is important to love nature more), 0.57 standard deviations higher on X6 (i.e., it is important to avoid war) respectively (see SI Table B2). The model indices are listed as follows: Chi-square to degree of freedom $\mathrm{X}^{2}(12)$ $=15.020$ with $p>0.05$ (>0.05), Comparative fit index (CFI) is $0.996(\geq 0.95)$, Root Mean Square Error of Approximation (RMSEA) is $0.034(\leq 0.05)$ and Standardized Root Mean Squared Residual (SRMR) is $0.025(\leq 0.08)$. Like the Alpha reliability $(\propto=0.890)$, this goodness of fit model resulted from dropping two items: X8: It is important to have equal opportunities and X9: It is important to take care of those who are worse off (see Figure 1).

As already computed, the Cronbach's alphas $(\propto=0.890)$ exceed the criteria value of 0.7 , indicating a high degree of internal consistency. The composite reliability $(\mathrm{CR})=0.895(>0.70)$, shows reliability of the construct. The average variance extracted $(\mathrm{AVE})=0.556(>0.50)$ demonstrates the construct was established with satisfactory convergent validity. The internal reliability (rho) ( $p=$ 0.899 ) indicates that the variation in the scale is $89.9 \%$ explained by the construct (see SI Table B3). 


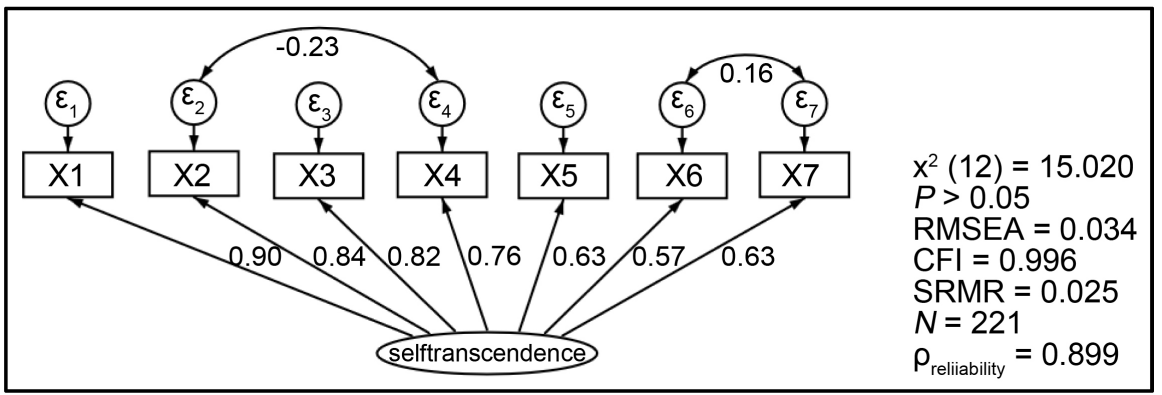

Figure 1. Result of Confirmatory Factor Analysis (CFA). Note: X1: It is important to love nature more; X2: It is important to stop environmental pollution; X3: It is important to protect and preserve environment; X4: It is important we shall live with nature; X5: It is important to help each other; X6: It is important to avoid war and X7: It is important to have equal justice.

\subsection{Balance Test}

The test assumed that the respondents assigned to either the control or testing group differed only in their access to education. To show that the statement is true, a balance test was conducted on six covariates, including age, gender, spouse, COVID-19 concerns, volunteerism, and self-transcendence. The test used $t$-tests as a means for comparison to check if there is statistically significant difference between the two groups. As a result, the null hypothesis that the true difference in means of each covariate is equal to 0 is not rejected (Table 1). So, the above-mentioned assumption holds.

\subsection{Econometrics Analysis}

To generate causal estimates of the effects of overseas educational experiences on waste separation behavior, I employed an econometrics analysis, the Instrumental Variable (IV) design. The intent is to test if there is statistically significant difference between the testing group (the group experiencing overseas education) and the control group (the group experiencing only local education), in terms of their behaviors and knowledge towards waste separation. So, the testing group is a binary variable ( $1=$ overseas educational experience, $0=$ otherwise). Though this is not the case for the control group, each group is also endogenous to general education. So, I instrumented the testing group (endogenous regressor) by education level (instrument).

I estimated a two-stage least squares (2SLS) strategy with the following equation:

\section{First-stage regression:}

$$
\text { Testing }_{i j}=k+\gamma E L_{i}+\theta_{i c}+\omega X_{i j}+\int_{i j}
$$

where Testing is a binary indicator of the individual $i$ experiencing overseas education $j$. Education Level ( $E L)$ denotes the level of general education that individual $i$ has attained so far. Since social behavior and barriers to recycling can differ tremendously between areas [81], I controlled country-level fixed effects $(\theta)$ that individual $i$ is living in a country $c . X$ is a vector of covariates of individual 
Table 1. Balance test between control and testing group.

\begin{tabular}{cccc}
\hline Covariate & $\begin{array}{c}\text { Control Group } \\
(\text { Mean })\end{array}$ & $\begin{array}{c}\text { Testing Group } \\
(\text { Mean })\end{array}$ & $\begin{array}{c}\text { Group Comparison } \\
(p \text {-value })\end{array}$ \\
\hline Age & 30.385 & 31.213 & $p=0.402$ \\
Gender & 0.517 & 0.625 & $p=0.149$ \\
Spouse & 0.534 & 0.422 & $p=0.142$ \\
COVID-19 & 2.474 & 2.343 & $p=0.373$ \\
Volunteerism & 0.701 & 0.664 & $p=0.608$ \\
Self-transcendence & 5.343 & 5.253 & $p=0.340$ \\
\hline
\end{tabular}

$i$ experiencing overseas education $j$.

Second-stage estimation:

$$
Y_{i j}=\propto+\beta \text { Testing }_{i j}+\phi_{i c}+\varphi X_{i j}+\varepsilon_{i j}
$$

\section{Results and Discussion}

Table 2 below presents the results of the Ordinary Least Square (OLS) regression, the first and second-stage regression of the Instrumental Variable (IV) model. An instrumental variable must not be correlated with the equation's disturbance $\epsilon$, and it must be highly correlated with the included endogenous regressor. As recommended by [82], the partial $R^{2}$ and $F$-statistic of the identifying instruments first-stage regression are useful indicators of the quality of the IV estimates and should be reported. It shows the strength of instrument. According to [83] [84], an $F$-statistic less than 10 is cause for concern or means that our instrument is weak. After being tested, the resulting $F$-statistic of each model is higher than 10 with $p<0.01$, meaning that the instrument is not weak.

As a result, overseas educational experience obviously gave Cambodian fellows not only academic experience, but also consciousness of the need for waste recycling and practical ability. Waste separation as a practice which was found statistically significant at $5 \%$ level $(\beta=1.060, p<0.05)$ is not surprising (regression 3; Table 2) considering Japan rules, for instance, that waste separation at source is compulsory. However, the practice sharply decreased and become statistically insignificant $(\beta=0.378, p>0.05)$ upon controlling fixed effects (regression 4 ; Table 2). So, the variation in waste separation practice is more likely explained by situational factor, the access to an effective waste management system particularly.

This result reflects the significant role of waste management system in managing solid waste of either country. In Cambodia, waste separation is neither mandatory at source, nor practical at waste management system. Therefore, people, no matter how knowledgeable they are, will be less likely to practice waste separation while facing inconvenient circumstances. Though waste separation practice of those Cambodian fellows becomes habituated [31] [32] [37] [38] [85] [86] while being in Japan, it will become gradually extinguished when encountering a new context where previous behavior becomes shaped differently 
Table 2. Effect of overseas educational experience on waste-separation practice.

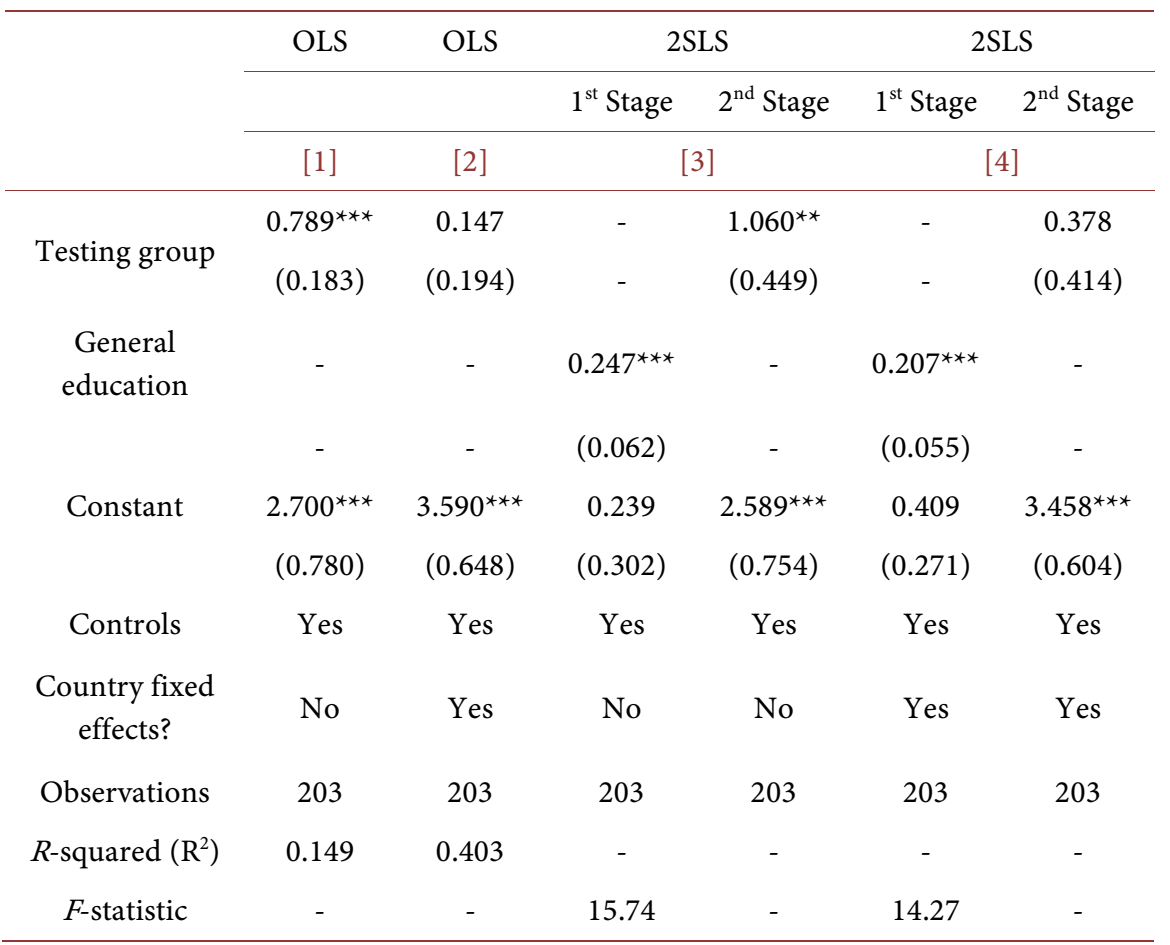

Standard errors are in parentheses. ${ }^{* *} p<0.01,{ }^{* *} p<0.05,{ }^{*} p<0.10$.

\section{[34] [35] [36] [87].}

This finding is consistent with previous studies, citing that knowledge alone doesn't convince people to practice waste recycling [27] [28] [29] [30] [41], until it is combined with accessibility to recycling or convenience [20]-[26] [88]. Waste separation behavior is obviously determined by waste management facilities and social context [89]-[94]. Therefore, the fellows are neither to adhere to responsible waste separation upon their return home since they had realized that formalized and widespread waste collection system in their municipality has not evolved.

Similarly, overseas educational experience could not even facilitate environmental knowledge change which is unexpected and different from previous studies [27] [41] [42]. No statistically significant difference was detected between the testing group and control group in terms of the five items used to assess the knowledge change. The fellows all had similar understanding on waste problems. They appeared to disagree with the statements that waste separation is difficult ( $\beta=-0.243, p>0.05$ ), waste separation is impossible until there is an active participation from their neighbors $(\beta=-0.905, p>0.05)$ and waste separation is impossible until there is support from their family members $(\beta=-0.532$, $p>0.05)$. However, the fellows experiencing oversea education seemed to have stronger commitment on time allocated for waste separation $(\beta=-0.773, p<$ 0.10 ), particularly as soon as an improved waste collection system is installed. The fellows realize that a clean society is more likely achieved with an improved 
waste management system $(\beta=0.639, p>0.05)$. The indicator: "Is improved waste collection system necessary?" is positive though it is statistically insignificant (regression 3; Table 3).

Those fellows who felt concern with COVID-19 infection seemed to find waste-separation difficult and complicated $(\beta=0.165, p<0.10)$ and they appeared to allocate their time for taking care of their health rather than waste separation $(\beta=0.236, p<0.01)$. It is a logic that when both our physical and mental health are severely affected by COVID-19, our daily routine including waste management practice will also be affected [77]. It should be the municipality to take overall responsibilities for municipal solid waste management, particularly in this pandemic, they insisted $(\beta=0.175, p<0.10)$ (regression 4 ; SI Tables B4-B6).

On contrary, people with self-transcendence values expressed their opinion in an opposite way. They appeared to be able to allocate their time to do waste-separation $(\beta=-0.422, p<0.01)$ which they found not difficult $(\beta=$ $-0.388, p<0.01)$. They seemed to be ready to spend their time sorting their garbage for a better environment (regression 4; SI Tables B4-B6). This result is parallel with the previous result, citing that people would spend time on pro-environmental activities if they realized the environmental problems and they could mitigate them [95]. For those fellows who got married, they disagreed waste sorting needs involvement of the neighbors $(\beta=-0.423, p<0.10)$ (regression 4; SI Table B7), while those fellows experiencing clean-up activities (i.e., volunteering) disagreed waste sorting needs the involvement of family members $(\beta=-0.284, p<0.10)($ regression 4; SI Table B8).

Table 3. Effect of overseas educational experience on knowledge change.

\begin{tabular}{cccccc}
\hline & $\begin{array}{c}\text { Is waste } \\
\text { separation } \\
\text { difficult? }\end{array}$ & $\begin{array}{c}\text { Don't you } \\
\text { have time } \\
\text { for waste } \\
\text { separation? }\end{array}$ & $\begin{array}{c}\text { Is improved } \\
\text { waste } \\
\text { collection } \\
\text { system } \\
\text { necessary? }\end{array}$ & $\begin{array}{c}\text { Does waste } \\
\text { sorting need } \\
\text { involvement } \\
\text { of our }\end{array}$ & $\begin{array}{c}\text { Does waste } \\
\text { sorting need } \\
\text { neighbors? } \\
\text { involvement } \\
\text { of family } \\
\text { members? }\end{array}$ \\
\cline { 2 - 6 } & [1] & {$[2]$} & {$[3]$} & {$[4]$} & {$[5]$} \\
Testing group & -0.243 & $-0.773^{*}$ & 0.639 & -0.905 & -0.532 \\
Constant & $5.252^{* * *}$ & $4.969^{* * *}$ & $4.856^{* * *}$ & $3.556^{* * *}$ & $4.390^{* * *}$ \\
Controls & $(0.799)$ & $(0.574)$ & $(0.976)$ & $(0.740)$ & $(0.717)$ \\
Country fixed & Yes & Yes & Yes & Yes & Yes \\
effects? & Yes & Yes & Yes & Yes & Yes \\
Observations & 206 & $20.458)$ & $(0.574)$ & $(0.625)$ & $(0.473)$ \\
F-statistic & 15.40 & 15.40 & 16.22 & 15.17 & 15.56 \\
\hline
\end{tabular}

Standard errors are in parentheses. ${ }^{\star * \star} p<0.01,{ }^{* *} p<0.05,{ }^{\star} p<0.10$. 
By the way, volunteerism (i.e., past volunteering in clean-up activities) is the only variable found statistically significant $(\beta=0.497, p<0.05)$ in explaining the variation in waste separation practice which is consistent with the previous study of [47]. Noticeably, its interaction effect with the coefficient of overseas educational experience makes the model statistically significant at $5 \%$ level with $F$-statistic $=156.42$. The insignificance of overidentification test $\mathrm{X}^{2}(1, N=203)=$ $0.077 ; p=0.781$ confirms the validity of the model (regression 5, SI Table B9). Thus, this finding implies that people experiencing overseas education and voluntarily engaging in clean-up activities more likely practice waste separation for environment's sake no matter how inconvenient the waste management system or facilities is. So, social factors are unlikely the barrier concerning waste-separation practice which is beyond the facts claimed by previous studies.

Nevertheless, Self-transcendence values (i.e., biosphere plus altruism) were unlikely the determinant of waste separation practice, even though it has been regarded as the foundation for any interventions to promote waste separation behavior [51] [52]. Its interaction effect was not significant $(\beta=0.088, p>0.05)$ with small $F$-statistic $=10.65$ (regression 6; SI Table B9). This is likely from the fact that a variety of behaviors are not always explained by human values [54] and a predictor of one behavior is unlikely the predictor of the others [21]. Values appeared to affect behaviors more influenced by personality traits. For instance, a study found that values or identity was one of determinants of plastic consumption behavior [96] and another study found that altruistic people more likely, for the sake of environment and its enjoyment, engaged in beach clean-up activities [56].

Though gender did play a crucial role in predicting pro-environmental intentions (SI Table B10 \& Table B11) [88] [97] [98] [99] [100], this study didn't find its effect on waste-sorting practice, but shopping-bag usage $(\beta=-0.507, p<$ 0.01) (regression 4; SI Table B12). From the correlation matrix (SI Table B13), female respondents are more concerned with environmental and social issues $(r=$ $-0.23, p<0.05)$ [101] [102] [103] and whereby more engage in environmental and social affairs voluntarily $(r=-0.18, p<0.01)$. So, any interventions designed to promote pro-environmental behaviors more likely be met with more success if oriented to participants regardless of gender. Different from [41], this study did not find any spousal influence on both waste-separation and shopping-bag usage.

The findings of this study obviously provide insights on how the eco-innovations, a way of creating a successful circular economy [104] as cited by [105], are performed particularly in developing countries where waste management system and recycling facilities are under development. Waste-sorting practices among consumers, known as a type of 3 Rs (i.e., reduction, reuse and recycle), is the environmentally responsible behavior required for the success of circular economy [106] [107] [108] [109] which is seen as a component towards achieving the UN Sustainable Development Goals (SDG), i.e., SDG 12: Responsible Consumption 
and Production [110].

Among the three determinants of eco-innovations (i.e., policy and regulation, supply side and demand side determinant), this study suggested to act immediately and as a priority regarding the policy and supply side determinant. The Best Environmental Practices (BEP) provided in the Stockholm Convention National Implementation Plan (NIP) which is being implemented by developing countries [112] will be more effective if attitudinal factors (i.e., volunteering, and self-transcendence values) which is also found in Europe as an inevitable one [113], are considered. Community-based Waste Management approach, an alternative to convince more and more engagement from the public in waste management [114], shall be promoted in the policy as well. It has been found as a solution to raise public awareness as well as to mobilize people to voluntarily participate and ensure the cleanliness in a community (i.e., to monitor and prevent waste disposal).

Nevertheless, at supply side, waste management system and recycling facilities at municipality level shall be upgraded as well. The better the waste management system is, the more convenient people will feel, whereby more public participation in waste management is expected [20]-[25]. For demand side (i.e., consumer needs), in addition to theoretical knowledge and know-how, increasing people interest in the value of nature is important. This study suggested to design a comprehensive environmental education program (i.e., theories, practices, and technology) in educational institutes, especially among children [9] [10] [114].

\section{Robustness Check}

Since the waste-separation practice is insignificant, the waste-separation intention among the fellows might be statistically insignificant too, according to the theory of planned behavior [46]. In developing country like Cambodia where waste collection facilities are still conventional and not yet upgraded, waste-separation will be feasible for only two purposes -for compost or for sale. Respondents of either group (i.e., testing group and control group) are unlikely to have intention to separate their garbage for compost or even for sale. Respondents were then asked to rate the 5-point Likert scale on three items for 1): "I plan to separate my garbage into organic and non-organic", 2): "I will sell my garbage separated" and 3): "I will compost my garbage separated". Participants responded on a 5 -point scale ( $0=$ most unlikely to $4=$ most likely).

From Table 4 below, as expected the three coefficients are all negative and statistically insignificant, except the item, "I plan to compost my garbage sorted". Therefore, we can assume that overseas education does not increase further the variation in the waste-separation intention among the respondents which is inconsistent with previous studies that showed a significant relationship between intention and past behavior [44] [45] [115] [116] as cited by [43]. See SI Table B14 for full regression. Anyhow, overseas education appeared to make the fellows find waste-sorting for compost impossible $(\beta=-1.291, p<0.05)$. 
Table 4. Effect of overseas educational experience on waste-sorting intentions.

\begin{tabular}{|c|c|c|c|c|c|c|}
\hline & \multicolumn{2}{|c|}{ 2SLS } & \multicolumn{2}{|c|}{ 2SLS } & \multicolumn{2}{|c|}{ 2SLS } \\
\hline & $1^{\text {st }}$ Stage & $2^{\text {nd }}$ Stage & $1^{\text {st }}$ Stage & $2^{\text {nd }}$ Stage & $1^{\text {st }}$ Stage & $2^{\text {nd }}$ Stage \\
\hline & \multicolumn{2}{|c|}{$[1]$} & \multicolumn{2}{|c|}{$[2]$} & \multicolumn{2}{|c|}{ [3] } \\
\hline \multirow{2}{*}{ Testing group } & - & -0.122 & - & -0.441 & - & $-1.291^{\star *}$ \\
\hline & - & $(0.312)$ & - & $(0.434)$ & - & $(0.544)$ \\
\hline \multirow[t]{2}{*}{$\begin{array}{l}\text { General } \\
\text { education }\end{array}$} & $0.215^{\star * *}$ & - & $0.214^{* * *}$ & - & $0.214^{* * *}$ & - \\
\hline & $(0.054)$ & - & $(0.054)$ & - & $(0.055)$ & - \\
\hline \multirow[t]{2}{*}{ Constant } & 0.408 & $2.232^{* * *}$ & 0.408 & $3.017^{\star * *}$ & 0.410 & $1.457^{\star}$ \\
\hline & $(0.271)$ & $(0.645)$ & $(0.271)$ & $(0.597)$ & $(0.270)$ & $(0.804)$ \\
\hline Controls & Yes & Yes & Yes & Yes & Yes & Yes \\
\hline $\begin{array}{c}\text { Country fixed } \\
\text { effects? }\end{array}$ & Yes & Yes & Yes & Yes & Yes & Yes \\
\hline Observations & 205 & 205 & 205 & 205 & 206 & 206 \\
\hline$F$-statistic & 15.59 & - & 15.59 & - & 15.40 & - \\
\hline
\end{tabular}

Note: [1]: I plan to sort my garbage into organic and non-organic; [2]: I plan to sell my garbage sorted; [3]: I plan to compost my garbage sorted. Standard errors are in parentheses. ${ }^{* *} p<0.01,{ }^{* *} p<0.05,{ }^{*} p<0.10$.

The shopping-bag usage behavior, where it is more influenced by personality traits than social factors; was tested and found statistically significant at $10 \%$ level $(\beta=0.834, p<0.10)$ (regression 4; full results are in SI Table B12). Experiencing overseas education contributes to increasing the probability of using shopping bag (SI Table B15). Thus, the variation in shopping-bag usage behavior was indeed unexplained by situational factor. The fellows that had used shopping bag were not influenced by the new context and they seemed to keep practicing this behavior regardless of the places they reside in.

This could result from the existing capacity among the fellows, as claimed previously that people who have environmental knowledge can make more informed decisions on how and what to consume and dispose [11] [12] as cited by [13] [14] [15] [28] [30] [117] [118]. In this sense, the capacity related to waste management or disposal of either group (i.e., testing group and control group) appears to be not significantly different.

\section{Conclusions}

The overseas educational experience is partially linked to knowledge change among Cambodian graduates. Understanding that a clean society basically rests on the waste management system governed by the municipality, the willingness to separate waste became less likely upon their arrival at their home country, Cambodia, where solid waste management systems are not convenient or functionally unreliable. Thereby, waste separation practice was not detected as well 
which could result from the absence of waste collection stations, and waste collection schedule or convenient waste separation is a disincentive to maintain enthusiasm, etc.

However, past volunteering in clean-up activities was found as the only predictor significantly associated with waste-separation practice and its interaction effect with the coefficient of overseas education contributes to increasing the probability of sorting garbage even in an inconvenient context. Conversely, human concerns about the environment and social welfare (i.e., self-transcendence) were seen as fundamental to promoting intentions rather than the practice toward waste separation. This finding proves that there is indeed a value-action gap, particularly for social influence-based practices (i.e., waste-sorting). This finding suggested promoting volunteering among children and teenagers which could be made via its application in the NIP, the community-based waste management approach, the Early Childhood Learning Program within the national educational system as recommended by [9] [10] or the experiential learning program [119].

This study was conducted targeting only those Cambodians with higher education. With an average age of 30 years old and standard deviation of 6 years, the respondents of this study were in the minority at the educational institutions. This group represents merely $6.7 \%$ of those persons aged 25 and above who have attained post-secondary education [120]. So, these study results cannot be generalized to Cambodian people. People at the household level should be targeted as respondents of future research to provide a wider platform of information for policy and facility development. Looking at a different field of volunteering (i.e., volunteering in social welfares) is another possibility to see its effect on pro-environmental practices.

There is doubt regarding the effect of "self-transcendence" on waste sorting practice. Since [55] and [56] confirmed altruism has a relationship with pro-environmental behaviors, the combined altruism and biosphere into one-dimension, self-transcendence, should expectedly increase its strength and sensitivity. If so, its effect on pro-environment behaviors is stronger and can be statistically detected more easily. However, it was not the case in this study. So, whether this one-factor or two-factor construct is better at predicting pro-environmental behaviors should be further explored.

\section{Data Availability Statement}

The data that support the findings of this study are available from the corresponding author upon reasonable request.

\section{Acknowledgements}

The authors would like to thank all respondents who spent valuable time filling the questionnaires surveyed. Gratitude should go to the Cambodian Student Association in Japan (CSAJ) and the Hiroshima Alumni Network for coopera- 
tion. This study would have not been possible without the two organizations. Finally, special gratefulness is sent to the Samdhana Institute (SI) for sponsoring the publication of this article.

\section{Disclaimers}

The views expressed in this paper are those of the authors and do not reflect the official policy or position of the Samdhana Institutue (SI).

\section{Conflicts of Interest}

The author declares no conflicts of interest regarding the publication of this paper

\section{References}

[1] Oskamp, S. (2000) Psychological Contributions to Achieving an Ecologically Sustainable Future for Humanity. Journal of Social Issues, 56, 373-390. https://doi.org/10.1111/0022-4537.00173

[2] UN (2017) World Population Projected to Reach 9.8 Billion in 2050, and 11.2 Billion in 2100. UN DESA. United Nations Department of Economic and Social Affairs.

https://www.un.org/development/desa/en/news/population/world-population-pros pects-2017.html

[3] UNEP (2021) Solid Waste Management. https://www.unep.org/explore-topics/resource-efficiency/what-we-do/cities/solid-w aste-management

[4] Pierre, D. (2002) Regional Development and Inter-Industry Recycling Linkages: Some Historical Perspectives. Entrepreneurship \& Regional Development, 14, 49-65. https://doi.org/10.1080/08985620110096627

[5] Korhonen, J., Honkasalo, A. and Seppälä, J. (2018) Circular Economy: The Concept and Its Limitations. Ecological Economics, 143, 37-46.

https://doi.org/10.1016/j.ecolecon.2017.06.041

[6] Ministry of the Environment Government of Japan (2021) A Sound Material-Cycle Society through the Eyes of Hokusai 2008.

https://www.env.go.jp/en/recycle/smcs/index.html

[7] Blankenberg, A.-K. and Alhusen, H. (2018) On the Determinants of Pro-Environmental Behavior-A Guide for Further Investigations. SSRN Electronic Journal, 350. https://doi.org/10.2139/ssrn.3186089

[8] Thøgersen, J. (1996) Recycling and Morality: A Critical Review of the Literature. Environment and Behavior, 28, 536-558. https://doi.org/10.1177/0013916596284006

[9] Chawla, L. (1998) Significant Life Experiences Revisited: A Review of Research on Sources of Environmental Sensitivity. Environmental Education Research, 4, 369-382. https://doi.org/10.1080/1350462980040402

[10] Dunkley, R.A. (2016) Learning at Eco-Attractions: Exploring the Bifurcation of Nature and Culture through Experiential Environmental Education. Journal of Environmental Education, 47, 213-221. https://doi.org/10.1080/00958964.2016.1164113

[11] Johansson, K. (2016) Understanding Recycling Behavior: A Study of Motivational Factors behind Waste Recycling. Waste Management and the Environment VIII, 1, 401-414. https://doi.org/10.2495/WM160361 
[12] Lester, B.T., Ma, L., Lee, O. and Lambert, J. (2006) Social Activism in Elementary Science Education: A Science, Technology, and Society Approach to Teach Global Warming. International Journal of Science Education, 28, 315-339. https://doi.org/10.1080/09500690500240100

[13] Gottlieb, D., Vigoda-Gadot, E. and Haim, A. (2013) Encouraging Ecological Behaviors among Students by Using the Ecological Footprint as an Educational Tool: A Quasi-Experimental Design in a Public High School in the City of Haifa. Environmental Education Research, 19, 844-863.

https://doi.org/10.1080/13504622.2013.768602

[14] Gamba, R. and Oskamp, S. (1994) Factors Influencing Community Residents' Participation in Commingled Curbside Recycling Programs. Environmental and Behavior, 26, 587-612. https://doi.org/10.1177/0013916594265001

[15] De Young, R. (1990) Recycling as Appropriate Behavior: A Review of Survey Data from Selected Recycling Education Programs in Michigan. Resources, Conservation and Recycling, 3, 253-266. https://doi.org/10.1016/0921-3449(90)90022-V

[16] De Feo, G. and De Gisi, S. (2010) Public Opinion and Awareness towards MSW and Separate Collection Programmes: A Sociological Procedure for Selecting Areas and Citizens with a Low Level of Knowledge. Waste Management, 30, 958-976.

https://doi.org/10.1016/j.wasman.2010.02.019

[17] Yeow, P.H.P. and Loo, W.H. (2018) Determinants of Consumer Behavior Regardingg Reusing, Refurbishing, and Recycling Computer Waste: An Exploratory Study in Malaysia. International Journal of Business and Information, 13, 457-488.

[18] Ma, J., Hipel, K.W., Hanson, M.L., Cai, X. and Liu, Y. (2018) An Analysis of Influencing Factors on Municipal Solid Waste Source-Separated Collection Behavior in Guilin, China by Using the Theory of Planned Behavior. Sustainable Cities and Society, 37, 336-343. https://doi.org/10.1016/j.scs.2017.11.037

[19] Prestin, A. and Pearce, K.E. (2010) We Care a Lot: Formative Research for a Social Marketing Campaign to Promote School-Based Recycling. Resources, Conservation and Recycling, 54, 1017-1026. https://doi.org/10.1016/j.resconrec.2010.02.009

[20] Ando, A.W. and Gosselin, A.Y. (2005) Recycling in Multifamily Dwellings: Does Convenience Matter? Economic Inquiry, 43, 426-438.

https://doi.org/10.1093/ei/cbi029

[21] Barr, S. (2007) Factors Influencing Environmental Attitudes and Behaviors: A U.K. Case Study of Household Waste Management. Environment and Behavior, 39, 435-473. https://doi.org/10.1177/0013916505283421

[22] Owusu, V., Adjei-Addo, E. and Sundberg, C. (2013) Do Economic Incentives Affect Attitudes to Solid Waste Source Separation? Evidence from Ghana. Resources, Conservation and Recycling, 78, 115-123. https://doi.org/10.1016/j.resconrec.2013.07.002

[23] Miafodzyeva, S. and Brandt, N. (2013) Recycling Behaviour among Householders: Synthesizing Determinants via a Meta-Analysis. Waste and Biomass Valorization, 4 , 221-235. https://doi.org/10.1007/s12649-012-9144-4

[24] Zhang, D., Huang, G., Yin, X. and Gong, Q. (2015) Residents' Waste Separation Behaviors at the Source: Using SEM with the Theory of Planned Behavior in Guangzhou, China. International Journal of Environmental Research and Public Health, 12, 9475-9491. https://doi.org/10.3390/ijerph120809475

[25] Loan, L.T.T., Nomura, H., Takahashi, Y. and Yabe, M. (2017) Psychological Driving Forces behind Households' Behaviors toward Municipal Organic Waste Separation at Source in Vietnam: A Structural Equation Modeling Approach. Journal of Ma- 
terial Cycles and Waste Management, 19, 1052-1060.

https://doi.org/10.1007/s10163-017-0587-3

[26] Bernstad, A. (2014) Household Food Waste Separation Behavior and the Importance of Convenience. Waste Management, 34, 1317-1323.

https://doi.org/10.1016/j.wasman.2014.03.013

[27] Ebreo, A. and Vining, J. (2000) Motives as Predictors of the Public's Attitudes toward Solid Waste Issues. Environmental Management, 25, 153-168.

https://doi.org/10.1007/s002679910012

[28] Sukholthaman, P. and Sharp, A. (2016) A System Dynamics Model to Evaluate Effects of Source Separation of Municipal Solid Waste Management: A Case of Bangkok, Thailand. Waste Management, 52, 50-61. https://doi.org/10.1016/j.wasman.2016.03.026

[29] Nguyen, T.N., Nguyen, H.V., Lobo, A. and Dao, T.S. (2017) Encouraging Vietnamese Household Recycling Behavior: Insights and Implications. Sustainability (Switzerland), 9, 179. https://doi.org/10.3390/su9020179

[30] Conke, L.S. (2018) Barriers to Waste Recycling Development: Evidence from Brazil. Resources, Conservation and Recycling, 134, 129-135. https://doi.org/10.1016/j.resconrec.2018.03.007

[31] Ajzen, I. (2002) Residual Effects of Past on Later Behavior: Habituation and Reasoned Action Perspectives. Personality and Social Psychology Review, 6, 107-122. https://doi.org/10.1207/S15327957PSPR0602_02

[32] Ouellette, J.A. and Wood, W. (1998) Habit and Intention in Everyday Life: The Multiple Processes by Which Past Behavior Predicts Future Behavior. Psychological Bulletin, 124, 54-74. https://doi.org/10.1037/0033-2909.124.1.54

[33] Ittiravivongs, A. (2012) Recycling as Habitual Behavior: The Impact of Habit on Household Waste Recycling Behavior in Thailand. Asian Social Science, 8, 74-81. https://doi.org/10.5539/ass.v8n6p74

[34] Verplanken, B. and Roy, D. (2016) Empowering Interventions to Promote Sustainable Lifestyles: Testing the Habit Discontinuity Hypothesis in a Field Experiment. Journal of Environmental Psychology, 45, 127-134. https://doi.org/10.1016/j.jenvp.2015.11.008

[35] Verplanken, B. and Wood, W. (2006) Interventions to Break and Create Consumer Habits. Public Policy \& Marketing, 25, 90-103. https://doi.org/10.1509/jppm.25.1.90

[36] Timlett, R.E. and Williams, I.D. (2009) The Impact of Transient Populations on Recycling Behaviour in a Densely Populated Urban Environment. Resources, Conservation and Recycling, 53, 498-506. https://doi.org/10.1016/j.resconrec.2009.03.010

[37] Tonglet, M., Phillips, P.S. and Read, A.D. (2004) Using the Theory of Planned Behaviour to Investigate the Determinants of Recycling Behaviour: A Case Study from Brixworth, UK. Resources, Conservation and Recycling, 41, 191-214. https://doi.org/10.1016/j.resconrec.2003.11.001

[38] Knussen, C. and Yule, F. (2008) "I'm Not in the Habit of Recycling": The Role of Habitual Behavior in the Disposal of Household Waste. Environment and Behavior, 40, 683-702. https://doi.org/10.1177/0013916507307527

[39] Pakpour, A.H., Zeidi, I.M., Emamjomeh, M.M., Asefzadeh, S. and Pearson, H. (2014) Household Waste Behaviours among a Community Sample in Iran: An Application of the Theory of Planned Behaviour. Waste Management, 34, 980-986. https://doi.org/10.1016/j.wasman.2013.10.028

[40] Pikturnienè, I. and Bäumle, G. (2016) Predictors of Recycling Behaviour Intentions 
among Urban Lithuanian Inhabitants. Journal of Business Economics and Management, 17, 780-795. https://doi.org/10.3846/16111699.2014.951957

[41] Davies, J., Foxall, G.R. and Pallister, J. (2002) Beyond the Intention-Behaviour Mythology: An Integrated Model of Recycling. Marketing Theory, 2, 29-113. https://doi.org/10.1177/1470593102002001645

[42] Xu, L., Ling, M. and Wu, Y. (2018) Economic Incentive and Social Influence to Overcome Household Waste Separation Dilemma: A Field Intervention Study. Waste Management, 77, 522-531. https://doi.org/10.1016/j.wasman.2018.04.048

[43] Ajzen, I. (2011) The Theory of Planned Behaviour: Reactions and Reflections. Psychology and Health, 26, 1113-1127. https://doi.org/10.1080/08870446.2011.613995

[44] Albarracín, D., Johnson, B.T., Fishbein, M. and Muellerleile, P.A. (2001) Theories of Reasoned Action and Planned Behavior as Models of Condom Use: A Meta-Analysis. Psychological Bulletin, 127, 142-161. https://doi.org/10.1037/0033-2909.127.1.142

[45] Sandberg, T. and Conner, M. (2008) Anticipated Regret as an Additional Predictor in the Theory of Planned Behaviour: A Meta-Analysis. British Journal of Social Psychology, 47, 589-606. https://doi.org/10.1348/014466607X258704

[46] Ajzen, I. (1991) The Theory of Planned Behavior. Organizational Behavior and Human Decision Processes, 50, 179-211. https://doi.org/10.1016/0749-5978(91)90020-T

[47] Matsumoto, S. (2020) Do Individuals Free Ride on Participation in Environmental Policies? Personal Values and Waste Management Practices. Ecological Economics, 174, Article ID: 106669. https://doi.org/10.1016/j.ecolecon.2020.106669

[48] Cnaan, R.A., Handy, F. and Wadsworth, M. (1996) Defining Who Is a Volunteer: Conceptual and Empirical Considerations. Nonprofit and Voluntary Sector Quarterly, 25, 364-383. https://doi.org/10.1177/0899764096253006

[49] Dawson, C., Baker, P.L. and Dowell, D. (2019) Getting into the "Giving Habit": The Dynamics of Volunteering in the UK. Voluntas, 30, 1006-1021.

https://doi.org/10.1007/s11266-019-00133-4

[50] Schwartz, S.H. (1992) Universals in the Content and Structure of Values: Theoretical Advances and Empirical Tests in 20 Countries. Advances in Experimental Social Psychology, 25, 1-65. https://doi.org/10.1016/S0065-2601(08)60281-6

[51] Thomas, C. and Sharp, V. (2013) Understanding the Normalisation of Recycling Behaviour and Its Implications for Other Pro-Environmental Behaviours: A Review of Social Norms and Recycling. Resources, Conservation and Recycling, 79, 11-20. https://doi.org/10.1016/j.resconrec.2013.04.010

[52] Crompton, T. and Kasser, T. (2009) Meeting Environmental Challenges: The Role of Human Identity. Panda House, Godalming. https://doi.org/10.1016/j.jenvp.2009.11.001

[53] Knez, I. (2016) Is Climate Change a Moral Issue? Effects of Egoism and Altruism on Pro-Environmental Behavior. Current Urban Studies, 4, 157-174. https://doi.org/10.4236/cus.2016.42012

[54] Maio, G.R. (2011) Don't Mind the Gap between Values and Action. Common Cause Briefing Paper. https://valuesandframes.org/resources/CCF_briefing_dont_mind_the_gap.pdf

[55] De Groot, J.I.M. and Steg, L. (2009) Mean or Green: Which Values Can Promote Stable Pro-Environmental Behavior? Conservation Letters, 2, 61-66. https://doi.org/10.1111/j.1755-263X.2009.00048.x

[56] De Dominicis, S., Schultz, P.W. and Bonaiuto, M. (2017) Protecting Environment 
for Self Interested Reasons: Altruism Is Not the Only Pathway to Sustainability. Frontiers in Psychology, 8, Article No. 1065. https://doi.org/10.3389/fpsyg.2017.01065

[57] Homer, P.M. and Kahle, L.R. (1988) A Structural Equation Test of the Value-Attitude-Behavior Hierarchy. Journal of Personality and Social Psychology, 54, 638-646. https://doi.org/10.1037/0022-3514.54.4.638

[58] McCarty, J.A. and Shrum, L.J. (1994) The Recycling of Solid Wastes: Personal Values, Value Orientations, and Attitudes about Recycling as Antecedents of Recycling Behavior. Journal of Business Research, 30, 53-62. https://doi.org/10.1016/0148-2963(94)90068-X

[59] McCarty, J.A. and Shrum, L.J. (2001) The Influence of Individualism, Collectivism, and Locus of Control on Environmental Beliefs and Behavior. Journal of Public Policy and Marketing, 20, 93-104. https://doi.org/10.1509/jppm.20.1.93.17291

[60] Latif, S.A. and Omar, M.S. (2012) Recycling Behaviour in Tioman Island: A Case Study. Procedia-Social and Behavioral Sciences, 36, 707-715. https://doi.org/10.1016/j.sbspro.2012.03.077

[61] Kurisu, K. (2016) Pro-Environmental Behaviors. Springer, Berlin. https://doi.org/10.1007/978-4-431-55834-7

[62] Onwezen, M.C., Antonides, G. and Bartels, J. (2013) The Norm Activation Model: An Exploration of the Functions of Anticipated Pride and Guilt in Pro-Environmental Behaviour. Journal of Economic Psychology, 39, 141-153. https://doi.org/10.1016/j.joep.2013.07.005

[63] Stern, P.C., Dietz, T. and Black, J.S. (1985) Support for Environmental Protection: The Role of Moral Norms. Population and Environment, 8, 204-222. https://doi.org/10.1007/BF01263074

[64] Guagnano, G.A., Stern, P.C. and Dietz, T. (1995) Influences on Attitude-Behavior Relationships: A Natural Experiment with Curbside Recycling. Environment and Behavior, 27, 699-718. https://doi.org/10.1177/0013916595275005

[65] Harland, P., Staats, H. and Wilke, H.A.M. (2007) Situational and Personality Factors as Direct or Personal Norm Mediated Predictors of Pro-Environmental Behavior: Questions Derived from Norm-Activation Theory. Basic and Applied Social Psychology, 29, 323-334. https://doi.org/10.1080/01973530701665058

[66] Kollmuss, A. and Agyeman, J. (2002) Mind the Gap: Why Do People Act Environmentally and What Are the Barriers to Pro-Environmental Behavior? Environmental Education Research, 8, 240-260. https://doi.org/10.1080/13504620220145401

[67] Stern, P.C. (2000) Toward a Coherent Theory of Environmentally Significant Behavior. Journal of Social Issues. The Society for the Psychological Study of Social Issues, 56, 407-424. https://doi.org/10.1111/0022-4537.00175

[68] Stern, P.C. (1998) A Brief Inventory of Values. Educational and Psychological Measurement, 58, 984-1001. https://doi.org/10.1177/0013164498058006008

[69] Boer, D. and Fischer, R. (2013) How and When Do Personal Values Guide Our Attitudes and Sociality? Explaining Cross-Cultural Variability in Attitude-Value Linkages. Psychological Bulletin, 139, 1113-1147. https://doi.org/10.1037/a0031347

[70] Schwartz, S.H. (2012) An Overview of the Schwartz Theory of Basic Values. Online Readings in Psychology and Culture, 2, 1-20. https://doi.org/10.9707/2307-0919.1116

[71] Wesley Schultz, P. and Zelezny, L. (1999) Values as Predictors of Environmental Attitudes: Evidence for Consistency across 14 Countries. Journal of Environmental 
Psychology, 19, 255-265. https://doi.org/10.1006/jevp.1999.0129

[72] Schultz, P.W. (2000) Empathizing with Nature: The Effects of Perspective Talking on Concern for Environmental Issues. Journal of Social Issues, 56, 391-406. https://doi.org/10.1111/0022-4537.00174

[73] Schultz, P.W. (2000) The Structure of Environmental Concern: Concern for Self, Other People, and the Biophere. Environmental Psychology, 21, 327-339. https://doi.org/10.1006/jevp.2001.0227

[74] Steg, L., Perlaviciute, G., van der Werff, E. and Lurvink, J. (2014) The Significance of Hedonic Values for Environmentally Relevant Attitudes, Preferences, and Actions. Environment and Behavior, 46, 163-192. https://doi.org/10.1177/0013916512454730

[75] Seng, B., Fujiwara, T. and Seng, B. (2018) Suitability Assessment for Handling Methods of Municipal Solid Waste. Global Journal of Environmental Science and Management, 4, 113-126.

[76] Hussain, M.W., Mirza, T. and Hassan, M.M. (2020) Impact of COVID-19 Pandemic on the Human Behavior. International Journal of Education and Management Engineering, 10, 35-61. https://doi.org/10.5815/ijeme.2020.05.05

[77] Bouman, T., Steg, L. and Kiers, H.A.L. (2018) Measuring Values in Environmental Research: A Test of an Environmental Portrait Value Questionnaire. Frontiers in Psychology, 9, Article 564. https://doi.org/10.3389/fpsyg.2018.00564

[78] Perlaviciute, G. and Steg, L. (2014) Contextual and Psychological Factors Shaping Evaluations and Acceptability of Energy Alternatives: Integrated Review and Research Agenda. Renewable and Sustainable Energy Reviews, 35, 361-381. https://doi.org/10.1016/j.rser.2014.04.003

[79] Alan, A.C. (2013) Discovering Structural Equation Modeling Using Stata. Stata Press Books, StataCorp LP, Number Dsemu, Texas.

[80] Fornell, C. and Larcker, D.F. (1981) Evaluating Structural Equation Models with Unobservable Variables and Measurement Error. Journal of Marketing Research, 18, 39. https://doi.org/10.2307/3151312

[81] Knickmeyer, D. (2020) Social Factors Influencing Household Waste Separation: A Literature Review on Good Practices to Improve the Recycling Performance of Urban Areas. Journal of Cleaner Production, 245, Article ID: 118605. https://doi.org/10.1016/j.jclepro.2019.118605

[82] Bound, J., Jaeger, D.A. and Baker, R.M. (1995) Problems with Instrumental Variables Estimation When the Correlation between the Instruments and the Endogenous Explanatory Variable Is Weak. Journal of the American Statistical Association, 90, 443-450. https://doi.org/10.1080/01621459.1995.10476536

[83] Staiger, D. and Stock, J.H. (1997) Instrumental Variables Regression with Weak Instruments. Econometrica, 65, 557. https://doi.org/10.2307/2171753

[84] Baum, C.F. (2006) An Introduction to Modern Econometrics Using Stata. Stata Press, Texas.

[85] Carrus, G., Passafaro, P. and Bonnes, M. (2008) Emotions, Habits and Rational Choices in Ecological Behaviours: The Case of Recycling and Use of Public Transportation. Journal of Environmental Psychology, 28, 51-62. https://doi.org/10.1016/j.jenvp.2007.09.003

[86] Xu, L., Ling, M., Lu, Y. and Shen, M. (2017) Understanding Household Waste Separation Behaviour: Testing the Roles of Moral, Past Experience, and Perceived Policy Effectiveness within the Theory of Planned Behaviour. Sustainability (Swit- 
zerland), 9, 625. https://doi.org/10.3390/su9040625

[87] Jansson, J., Marell, A. and Nordlund, A. (2010) Green Consumer Behavior: Determinants of Curtailment and Eco-Innovation Adoption. Journal of Consumer Marketing, 27, 358-370. https://doi.org/10.1108/07363761011052396

[88] Echegaray, F. and Hansstein, F.V. (2017) Assessing the Intention-Behavior Gap in Electronic Waste Recycling: The Case of Brazil. Journal of Cleaner Production, 142, 180-190. https://doi.org/10.1016/j.jclepro.2016.05.064

[89] Ekere, W., Mugisha, J. and Drake, L. (2009) Factors Influencing Waste Separation and Utilization among Households in the Lake Victoria Crescent, Uganda. Waste Management, 29, 3047-3051. https://doi.org/10.1016/j.wasman.2009.08.001

[90] do Valle, P.O., Reis, E., Menezes, J. and Rebelo, E. (2004) Behavioral Determinants of Household Recycling Participation: The Portuguese Case. Environment and Behavior, 36, 505-540. https://doi.org/10.1177/0013916503260892

[91] Oke, A. (2015) Workplace Waste Recycling Behaviour: A Meta-Analytical Review. Sustainability (Switzerland), 7, 7175-7194. https://doi.org/10.3390/su7067175

[92] Nguyen, T.T.P., Zhu, D. and Le, N.P. (2015) Factors Influencing Waste Separation Intention of Residential Households in a Developing Country: Evidence from Hanoi, Vietnam. Habitat International, 48, 169-176. https://doi.org/10.1016/j.habitatint.2015.03.013

[93] Liao, C., Zhao, D., Zhang, S. and Chen, L. (2018) Determinants and the Moderating Effect of Perceived Policy Effectiveness on Residents' Separation Intention for Rural Household Solid Waste. International Journal of Environmental Research and Public Health, 15, 726. https://doi.org/10.3390/ijerph15040726

[94] Klöckner, C.A. and Oppedal, I.O. (2011) General vs. Domain Specific Recycling Behaviour-Applying a Multilevel Comprehensive Action Determination Model to Recycling in Norwegian Student Homes. Resources, Conservation and Recycling, 55, 463-471. https://doi.org/10.1016/j.resconrec.2010.12.009

[95] Matsumoto, S. (2014) The Opportunity Cost of Pro-Environmental Activities: Spending Time to Promote the Environment. Journal of Family and Economic Issues, 35, 119-130. https://doi.org/10.1007/s10834-013-9354-3

[96] Heidbreder, L.M., Steinhorst, J. and Schmitt, M. (2020) Plastic-Free July: An Experimental Study of Limiting and Promoting Factors in Encouraging a Reduction of Single-Use Plastic Consumption. Sustainability (Switzerland), 12, Article No. 4698. https://doi.org/10.3390/su12114698

[97] Trelohan, M. (2021) Do Women Engage in Pro-Environmental Behaviours in the Public Sphere Due to Social Expectations? The Effects of Social Norm-Based Persuasive Messages. VOLUNTAS: International Journal of Voluntary and Nonprofit Organizations. https://doi.org/10.1007/s11266-020-00303-9

[98] Babaei, A.A., Alavi, N., Goudarzi, G., Teymouri, P., Ahmadi, K. and Rafiee, M. (2015) Household Recycling Knowledge, Attitudes and Practices towards Solid Waste Management. Resources, Conservation and Recycling, 102, 94-100. https://doi.org/10.1016/j.resconrec.2015.06.014

[99] Alhassan, H., Kwakwa, P.A. and Owusu-Sekyere, E. (2020) Households' Source Separation Behaviour and Solid Waste Disposal Options in Ghana's Millennium City. Journal of Environmental Management, 259, Article ID: 110055.

https://doi.org/10.1016/j.jenvman.2019.110055

[100] Patel, J., Modi, A. and Paul, J. (2017) Pro-Environmental Behavior and Socio-Demographic Factors in an Emerging Market. Asian Journal of Business Ethics, 6, 189-214. https://doi.org/10.1007/s13520-016-0071-5 
[101] MacDonald, W.L. and Hara, N. (1994) Gender Differences in Environmental Concern among College Students. Sex Roles, 31, 369-374. https://doi.org/10.1007/BF01544595

[102] Dietz, T., Kalof, L. and Stern, P.C. (2002) Gender, Values and Environmentalism. Social Science Quarterly, 83, 353-364. https://doi.org/10.1111/1540-6237.00088

[103] Xiao, C. and McCright, A.M. (2014) A Test of the Biographical Availability Argument for Gender Differences in Environmental Behaviors. Environment and Behavior, 46, 241-263. https://doi.org/10.1177/0013916512453991

[104] Scheel, C. (2016) Beyond Sustainability. Transforming Industrial Zero-Valued Residues into Increasing Economic Returns. Journal of Cleaner Production, 131, 376-386. https://doi.org/10.1016/j.jclepro.2016.05.018

[105] Prieto-Sandoval, V., Jaca, C. and Ormazabal, M. (2018) Towards a Consensus on the Circular Economy. Journal of Cleaner Production, 179, 605-615. https://doi.org/10.1016/j.jclepro.2017.12.224

[106] Yong, R. (2007) The Circular Economy in China. Journal of Material Cycles and Waste Management, 9, 121-129. https://doi.org/10.1007/s10163-007-0183-Z

[107] Geissdoerfer, M., Savaget, P., Bocken, N.M.P. and Hultink, E.J. (2017) The Circular Economy-A New Sustainability Paradigm? Journal of Cleaner Production, 143, 757-768. https://doi.org/10.1016/j.jclepro.2016.12.048

[108] Kirchherr, J., Reike, D. and Hekkert, M. (2017) Conceptualizing the Circular Economy: An Analysis of 114 Definitions. Resources, Conservation and Recycling, 127, 221-232. https://doi.org/10.1016/j.resconrec.2017.09.005

[109] Geng, Y., Sarkis, J. and Bleischwitz, R. (2019) How to Globalize the Circular Economy. Nature, 565, 153-155. https://doi.org/10.1038/d41586-019-00017-z

[110] UNIDO (2017) Cicular Economy. Vienna. https://www.unido.org/sites/default/files/2017-07/Circular_Economy_UNIDO_0.pd $\underline{\mathrm{f}}$

[111] UNIDO (2019) Circular Economy and the Stockholm Convention Division. Vienna.

https://www.unido.org/sites/default/files/files/2020-02/SC\%20and\%20Circular\%20E conomy.pdf

[112] Nainggolan, D., Pedersen, A.B., Smed, S., Zemo, K.H., Hasler, B. and Termansen, M. (2019) Consumers in a Circular Economy: Economic Analysis of Household Waste Sorting Behaviour. Ecological Economics, 166, Article ID: 106402. https://doi.org/10.1016/j.ecolecon.2019.106402

[113] UNDP (2019) Plastics and Circular Economy: Community Solutions. New York. https://www.cjsalomon.com

[114] Gao, C., Hou, H., Zhang, J., Zhang, H. and Gong, W. (2006) Education for Regional Sustainable Development: Experiences from the Education Framework of HHCEPZ Project. Journal of Cleaner Production, 14, 994-1002. https://doi.org/10.1016/j.jclepro.2005.11.043

[115] Conner, M., Sheeran, P., Norman, P. and Armitage, C.J. (2000) Temporal Stability as a Moderator of Relationships in the Theory of Planned Behaviour. British Journal of Social Psychology, 39, 469-493. https://doi.org/10.1348/014466600164598

[116] Rise, J., Sheeran, P. and Hukkelberg, S. (2010) The Role of Self-Identity in the Theory of Planned Behavior: A Meta-Analysis. Journal of Applied Social Psycholo$g y, 40,1085-1105$. https://doi.org/10.1111/j.1559-1816.2010.00611.x

[117] Chen, M.F. and Tung, P.J. (2014) Developing an Extended Theory of Planned Be- 
havior Model to Predict Consumers' Intention to Visit Green Hotels. International Journal of Hospitality Management, 36, 221-230.

https://doi.org/10.1016/j.ijhm.2013.09.006

[118] Xu, D.Y., Lin, Z.Y., Gordon, M.P.R., Robinson, N.K.L. and Harder, M.K. (2016) Perceived Key Elements of a Successful Residential Food Waste Sorting Program in Urban Apartments: Stakeholder Views. Journal of Cleaner Production, 134, 362-370. https://doi.org/10.1016/j.jclepro.2015.12.107

[119] (Ray) Yen, C.D. and J.V. Sembiring, J.V. (2020) The Research of Experiential Learning to Enhance Ocean Stewardship and Pro-Environmental Behavior Intention-Cross-Cultural Comparison from Taiwan and Indonesia. Creative Education, 11, 1008-1025. https://doi.org/10.4236/ce.2020.117073

[120] NIS (2021) Cambodia Socio-Economic Survey 2019/20. Phnom Penh. https://www.nis.gov.kh/nis/CSES/Final\%20Report\%20of\%20Cambodia\%20Socio-E conomic\%20Survey\%202019-20_EN.pdf 


\section{Supplemental Information}

"The Effect of Overseas Educational Experience on Pro-Environmental Practices: Evidence from Cambodian Academic Scholars".

\section{1) How to dispose of Household Garbage}

In Japan, depending on the city, town, or district, there may be designated bags that residents are required to use for trash. In other words, the rules for separating and disposing of garbage depend on the local municipality. Many municipal offices provide pamphlets (Figure A1) that explain the rules of garbage disposal. Waste sorting at household level is strict.

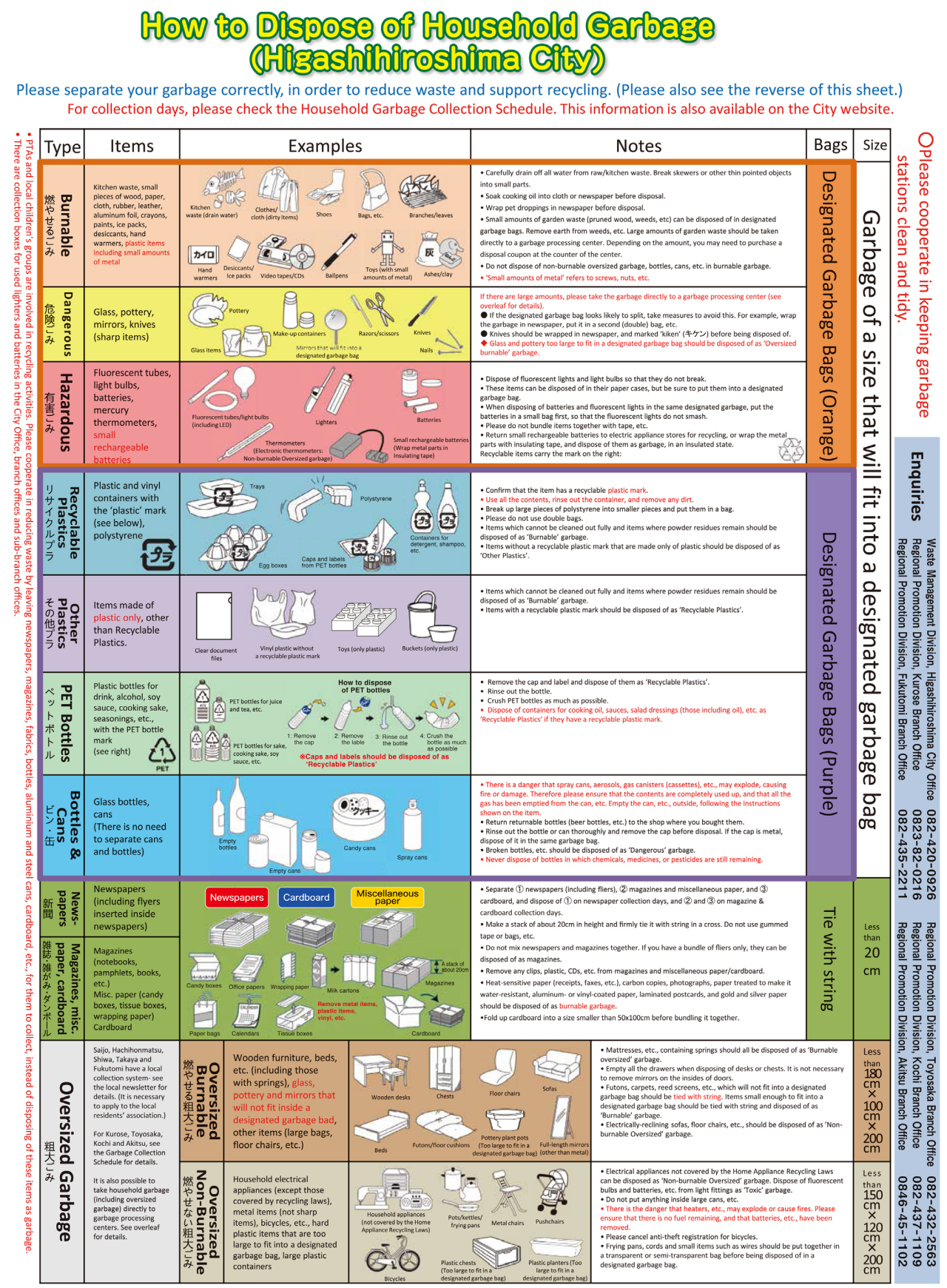

Figure A1. Guideline for household garbage disposal in Higashi-Hiroshima city, Japan. 


\section{2) Supplementary Tables}

Table B1. Descriptive statistics of the variables assigned as outcomes and controls.

\begin{tabular}{|c|c|c|c|c|c|}
\hline & Variables & Mean or share & SD & Min & $\operatorname{Max}$ \\
\hline How often you sepa & & 2.64 & 1.25 & 0 & 4 \\
\hline How often you bring & own shopping bag & 2.63 & 0.98 & 0 & 4 \\
\hline I find waste separati & cult & 2.74 & 1.11 & 0 & 4 \\
\hline I do not have time to & te waste & 2.23 & 0.87 & 0 & 4 \\
\hline Waste is never separ & my neighboring families & 3.42 & 1.08 & 0 & 4 \\
\hline Waste separation is & dired by collection service & 3.29 & 1.40 & 0 & 4 \\
\hline Waste separation is & ouraged by family members & 3.13 & 1.02 & 0 & 4 \\
\hline Self-transcendence $\mathrm{v}$ & $=0.899)$ & 5.27 & 0.62 & 3.28 & 6 \\
\hline $\mathrm{X} 1$ : It is important $\mathrm{t}$ & ature more & 5.32 & 0.78 & 2 & 6 \\
\hline $\mathrm{X} 2$ : It is important $\mathrm{t}$ & nvironmental pollution & 5.40 & 0.76 & 3 & 6 \\
\hline $\mathrm{X} 3$ : It is important to & t and preserve environment & 5.48 & 0.67 & 4 & 6 \\
\hline $\mathrm{X} 4$ : It is important $\mathrm{w}$ & live with nature & 5.20 & 0.81 & 2 & 6 \\
\hline $\mathrm{X} 5$ : It is important to & ach other & 4.88 & 0.83 & 2 & 6 \\
\hline X6: It is important to & war & 5.35 & 0.83 & 3 & 6 \\
\hline $\mathrm{X} 7$ : It is important to & qual justice & 5.30 & 0.87 & 3 & 6 \\
\hline Age & Years old & 30.97 & 6.37 & 18 & 52 \\
\hline Male & Dummy ( 1 = male $)$ & 0.59 & 0.49 & 0 & 1 \\
\hline Spouse & Dummy $(1=$ married $)$ & 0.45 & 0.49 & 0 & 1 \\
\hline Volunteerism & Dummy (1 = yes $)$ & 0.67 & 0.46 & 0 & 1 \\
\hline COVID-19 concern & $\begin{array}{l}1=\text { a little concerned }(19.73 \%), \\
2=\text { fairly concerned }(37.67 \%), \\
3=\text { very concerned }(27.80 \%) \text { and } \\
4=\text { extremely concerned }(14.80 \%)\end{array}$ & 2.37 & 0.96 & 1 & 4 \\
\hline
\end{tabular}

Table B2. Final results for single-factor CFA model.

\begin{tabular}{|c|c|c|}
\hline Loadings & Unstandardized Value & Standardized Value \\
\hline $\mathrm{X} 1$ : It is important to love nature more & 1.00 (fixed) & $0.90^{* * *}$ \\
\hline $\mathrm{X} 2$ : It is important to stop environmental pollution & $0.92^{\star * *}$ & $0.84^{\star * *}$ \\
\hline $\mathrm{X} 3$ : It is important to protect and preserve environment & $0.78^{\star * *}$ & $0.82^{\star * *}$ \\
\hline $\mathrm{X} 4:$ It is important we shall live with nature & $0.89^{\star * *}$ & $0.76^{\star * *}$ \\
\hline $\mathrm{X} 5$ : It is important to help each other & $0.75^{\star * *}$ & $0.63^{\star * *}$ \\
\hline X6: It is important to avoid war & $0.68^{\star * *}$ & $0.57^{\star * *}$ \\
\hline X7: It is important to have equal justice & $0.80^{\star * *}$ & $0.63^{\star * *}$ \\
\hline \multicolumn{3}{|l|}{ Variances } \\
\hline error. X1 & 0.12 & 0.20 \\
\hline error. X2 & 0.17 & 0.29 \\
\hline error. X3 & 0.15 & 0.33 \\
\hline error. X4 & 0.27 & 0.41 \\
\hline error. X5 & 0.42 & 0.60 \\
\hline error. X6 & 0.47 & 0.67 \\
\hline error. X7 & 0.46 & 0.60 \\
\hline Self-transcendence & 0.49 & 1.00 (fixed) \\
\hline \multicolumn{3}{|l|}{ Covariance } \\
\hline error. X2 with error. X4 & $-0.05^{\star *}$ & $-0.23^{*}$ \\
\hline error. X6 with error. X7 & $0.07^{\star}$ & $0.16^{\star}$ \\
\hline
\end{tabular}

${ }^{\star * *} p<0.001,{ }^{* *} p<0.01,{ }^{\star} p<0.05$. 
Table B3. Construct reliability and validity.

\begin{tabular}{|c|c|c|c|c|c|c|}
\hline Construct & Indicators & $\begin{array}{l}\text { Factor } \\
\text { loading }\end{array}$ & $\begin{array}{l}\text { Cronbach's } \\
\text { Alpha }\end{array}$ & AVE & CR & $\begin{array}{c}p \\
\text { (Rho) }\end{array}$ \\
\hline \multirow[t]{7}{*}{ Self-transcendence } & $\mathrm{X} 1$ : It is important to love nature more & $0.90^{* * *}$ & 0.890 & 0.556 & 0.895 & 0.899 \\
\hline & $\begin{array}{l}\mathrm{X} 2 \text { : It is important to stop environmental } \\
\text { pollution }\end{array}$ & $0.84^{* * *}$ & - & - & - & - \\
\hline & $\begin{array}{l}\mathrm{X} 3 \text { : It is important to protect and preserve } \\
\text { environment }\end{array}$ & $0.82^{\star * *}$ & - & - & - & - \\
\hline & $\mathrm{X} 4$ : It is important we shall live with nature & $0.76^{\star * *}$ & - & - & - & - \\
\hline & $\mathrm{X} 5$ : It is important to help each other & $0.63^{* * *}$ & - & - & - & - \\
\hline & X6: It is important to avoid war & $0.57^{* * *}$ & - & - & - & - \\
\hline & $\mathrm{X} 7$ : It is important to have equal justice & $0.63^{\star * *}$ & - & - & - & - \\
\hline
\end{tabular}

Note: ${ }^{* * *} p<0.001$. AVE: average variance extracted; CR: composite reliability.

Table B4. Effect of overseas educational experience on know-how toward waste separation.

\begin{tabular}{|c|c|c|c|c|c|c|}
\hline & \multirow[t]{2}{*}{ OLS } & \multirow[t]{2}{*}{ OLS } & \multicolumn{2}{|c|}{ 2SLS } & \multicolumn{2}{|c|}{ 2SLS } \\
\hline & & & $1^{\text {st }}$ Stage & $2^{\text {nd }}$ Stage & $1^{\text {st }}$ Stage & $2^{\text {nd }}$ Stage \\
\hline & {$[1]$} & [2] & & & & \\
\hline \multirow{2}{*}{ Testing group } & -0.223 & -0.189 & - & -0.263 & - & -0.243 \\
\hline & $(0.175)$ & $(0.193)$ & - & $(0.486)$ & - & $(0.583)$ \\
\hline \multirow[t]{2}{*}{ Male } & -0.257 & -0.249 & 0.041 & -0.264 & 0.001 & -0.260 \\
\hline & $(0.165)$ & $(0.164)$ & $(0.063)$ & $(0.161)$ & $(0.060)$ & $(0.160)$ \\
\hline \multirow[t]{2}{*}{ Age } & -0.011 & -0.012 & 0.002 & -0.011 & 0.009 & -0.012 \\
\hline & $(0.016)$ & $(0.017)$ & $(0.008)$ & $(0.017)$ & $(0.008)$ & $(0.019)$ \\
\hline \multirow[t]{2}{*}{ Spouse } & -0.306 & -0.305 & $-0.184^{\star *}$ & -0.288 & $-0.159^{* *}$ & -0.288 \\
\hline & $(0.204)$ & $(0.203)$ & $(0.075)$ & $(0.212)$ & $(0.074)$ & $(0.212)$ \\
\hline \multirow[t]{2}{*}{ Volunteerism } & -0.137 & -0.136 & -0.037 & -0.115 & -0.035 & -0.114 \\
\hline & $(0.166)$ & $(0.170)$ & $(0.062)$ & $(0.166)$ & $(0.058)$ & $(0.166)$ \\
\hline \multirow[t]{2}{*}{ COVID-19 } & $0.157^{\star}$ & $0.156^{\star}$ & -0.013 & $0.167^{\star}$ & 0.001 & $0.165^{\star}$ \\
\hline & $(0.083)$ & $(0.091)$ & $(0.033)$ & $(0.088)$ & $(0.030)$ & $(0.089)$ \\
\hline \multirow[t]{2}{*}{ Self-transcendence } & $-0.379^{* * *}$ & $-0.377^{\star \star *}$ & -0.028 & $-0.390^{\star * *}$ & -0.037 & $-0.388^{\star * *}$ \\
\hline & $(0.126)$ & $(0.118)$ & $(0.047)$ & $(0.114)$ & $(0.043)$ & $(0.114)$ \\
\hline \multirow[t]{2}{*}{ General education } & - & - & $0.253^{* * *}$ & - & $0.214^{\star * \star}$ & - \\
\hline & - & - & $(0.062)$ & - & $(0.055)$ & - \\
\hline \multirow[t]{2}{*}{ Constant } & $5.220^{\star * *}$ & $5.174^{\star * \star}$ & $0.556^{\star *}$ & $5.279^{* * *}$ & 0.410 & $5.252^{* * *}$ \\
\hline & $(0.759)$ & $(0.765)$ & $(0.216)$ & $(0.759)$ & $(0.270)$ & $(0.799)$ \\
\hline Country fixed effects? & No & Yes & No & No & Yes & Yes \\
\hline Observation $(N)$ & 207 & 207 & 206 & 206 & 206 & 206 \\
\hline $\mathrm{R}$-squared $\left(R^{2}\right)$ & 0.095 & 0.096 & - & - & - & - \\
\hline$F$-statistic & - & - & - & 16.76 & - & 15.40 \\
\hline
\end{tabular}

Standard errors are in parentheses. ${ }^{* *} p<0.01,{ }^{* *} p<0.05,{ }^{\star} p<0.1$. 
Table B5. Effect of overseas educational experience on time allocated for waste-separation.

\begin{tabular}{|c|c|c|c|c|c|c|}
\hline & \multirow[t]{2}{*}{ OLS } & \multirow[t]{2}{*}{ OLS } & \multicolumn{2}{|c|}{ 2SLS } & \multicolumn{2}{|c|}{ 2SLS } \\
\hline & & & $1^{\text {st }}$ Stage & $2^{\text {nd }}$ Stage & $1^{\text {st }}$ Stage & $2^{\text {nd }}$ Stage \\
\hline & {$[1]$} & {$[2]$} & & & & \\
\hline \multirow{2}{*}{ Testing group } & $-0.392^{* * *}$ & $-0.434^{\star * *}$ & - & $-0.666^{*}$ & - & $-0.773^{*}$ \\
\hline & $(0.148)$ & $(0.160)$ & - & $(0.388)$ & - & $(0.458)$ \\
\hline \multirow[t]{2}{*}{ Male } & -0.094 & -0.104 & 0.041 & -0.080 & 0.001 & -0.103 \\
\hline & $(0.128)$ & $(0.125)$ & $(0.063)$ & $(0.130)$ & $(-0.060)$ & $(0.124)$ \\
\hline \multirow[t]{2}{*}{ Age } & -0.011 & -0.008 & 0.002 & -0.006 & 0.009 & -0.001 \\
\hline & $(0.014)$ & $(0.014)$ & $(0.008)$ & $(0.014)$ & $(0.008)$ & $(0.016)$ \\
\hline \multirow[t]{2}{*}{ Spouse } & -0.212 & -0.213 & $-0.184^{* *}$ & -0.265 & $-0.159^{* *}$ & -0.267 \\
\hline & $(0.160)$ & $(0.162)$ & $(0.075)$ & $(0.173)$ & $(0.074)$ & $(0.176)$ \\
\hline \multirow[t]{2}{*}{ Volunteerism } & -0.153 & -0.154 & -0.038 & -0.158 & -0.035 & -0.159 \\
\hline & $(0.126)$ & $(0.126)$ & $(0.062)$ & $(0.123)$ & $(0.058)$ & $(0.124)$ \\
\hline \multirow[t]{2}{*}{ COVID-19 } & $0.231^{\star * *}$ & $0.235^{\star * \star}$ & -0.013 & $0.227^{\star * *}$ & 0.001 & $0.236^{* * *}$ \\
\hline & $(0.071)$ & $(0.072)$ & $(0.033)$ & $(0.072)$ & $(0.030)$ & $(0.071)$ \\
\hline \multirow[t]{2}{*}{ Self-transcendence } & $-0.409^{* * *}$ & $-0.413^{* * *}$ & -0.028 & $-0.413^{* * *}$ & -0.037 & $-0.422^{* * *}$ \\
\hline & $(0.083)$ & $(0.083)$ & $(0.047)$ & $(0.083)$ & $(0.043)$ & $(0.084)$ \\
\hline \multirow[t]{2}{*}{ General education } & - & - & $0.253^{* * *}$ & - & $0.214^{* * *}$ & - \\
\hline & - & - & $(0.062)$ & - & $(0.055)$ & - \\
\hline \multirow[t]{2}{*}{ Constant } & $4.707^{\star \star *}$ & $4.765^{\star * *}$ & $0.244^{* *}$ & $4.828^{\star * \star}$ & 0.410 & $4.969^{* * *}$ \\
\hline & $(0.551)$ & $(0.550)$ & $(0.301)$ & $(0.549)$ & $(0.270)$ & $(0.574)$ \\
\hline Country fixed effects? & No & Yes & No & No & Yes & Yes \\
\hline Observation $(N)$ & 207 & 207 & 206 & 206 & 206 & 206 \\
\hline R-squared $\left(R^{2}\right)$ & 0.175 & 0.177 & - & - & - & - \\
\hline$F$-statistic & - & - & - & 16.76 & - & 15.40 \\
\hline
\end{tabular}

Standard errors are in parentheses. ${ }^{* *} p<0.01,{ }^{* *} p<0.05,{ }^{*} p<0.1$.

Table B6. Effect of overseas educational experience on improved waste collection system.

\begin{tabular}{|c|c|c|c|c|c|c|}
\hline & \multirow[t]{2}{*}{ OLS } & \multirow[t]{2}{*}{ OLS } & \multicolumn{2}{|c|}{ 2SLS } & \multicolumn{2}{|c|}{ 2SLS } \\
\hline & & & $1^{\text {st }}$ Stage & $2^{\text {nd }}$ Stage & $1^{\text {st }}$ Stage & $2^{\text {nd }}$ Stage \\
\hline & [1] & [2] & & & & \\
\hline \multirow{2}{*}{ Testing group } & $0.738^{\star * *}$ & $0.553^{* *}$ & - & $0.826^{*}$ & - & 0.639 \\
\hline & $(0.218)$ & $(0.248)$ & - & $(0.491)$ & - & $(0.574)$ \\
\hline \multirow[t]{2}{*}{ Male } & -0.127 & -0.171 & 0.047 & -0.137 & 0.007 & -0.178 \\
\hline & $(0.202)$ & $(0.198)$ & $(0.063)$ & $(0.201)$ & $(0.059)$ & $(0.194)$ \\
\hline \multirow[t]{2}{*}{ Age } & $-2.15 e-06$ & 0.009 & 0.001 & 0.002 & 0.008 & 0.007 \\
\hline & $(0.019)$ & $(0.019)$ & $(0.008)$ & $(0.019)$ & $(0.008)$ & $(0.022)$ \\
\hline \multirow[t]{2}{*}{ Spouse } & -0.351 & -0.355 & $-0.170^{\star *}$ & -0.322 & $-0.147^{\star \star}$ & -0.326 \\
\hline & $(0.252)$ & $(0.252)$ & $(0.076)$ & $(0.254)$ & $(0.074)$ & $(0.254)$ \\
\hline \multirow[t]{2}{*}{ Volunteerism } & -0.049 & -0.055 & -0.026 & -0.038 & -0.024 & -0.041 \\
\hline & $(0.216)$ & $(0.218)$ & $(0.061)$ & $(0.214)$ & $(0.058)$ & $(0.215)$ \\
\hline \multirow[t]{2}{*}{ COVID-19 } & 0.154 & 0.168 & -0.023 & 0.161 & -0.008 & $0.175^{\star}$ \\
\hline & $(0.103)$ & $(0.102)$ & $(0.033)$ & $(0.102)$ & $(0.030)$ & $(0.101)$ \\
\hline \multirow[t]{2}{*}{ Self-transcendence } & $-0.376^{\star *}$ & $-0.392^{\star \star \star}$ & -0.027 & $-0.380^{\star \star \star}$ & -0.036 & $-0.396^{\star * *}$ \\
\hline & $(0.144)$ & $(0.144)$ & $(0.047)$ & $(0.142)$ & $(0.043)$ & $(0.143)$ \\
\hline \multirow[t]{2}{*}{ General education } & - & - & $0.266^{* * *}$ & - & - & - \\
\hline & - & - & $(0.063)$ & - & - & - \\
\hline \multirow[t]{2}{*}{ Constant } & $4.629^{\star * *}$ & $4.879^{* * *}$ & 0.231 & $4.608^{\star * *}$ & 0.395 & $4.856^{* * *}$ \\
\hline & $(0.920)$ & $(0.943)$ & $(0.300)$ & $(0.926)$ & $(0.270)$ & $(0.976)$ \\
\hline Country fixed effects? & No & Yes & No & No & Yes & Yes \\
\hline Observation $(N)$ & 206 & 206 & 205 & 205 & 205 & 205 \\
\hline R-squared $\left(R^{2}\right)$ & 0.096 & 0.113 & - & - & - & - \\
\hline$F$-statistic & - & - & - & 17.67 & - & 16.22 \\
\hline
\end{tabular}

Standard errors are in parentheses. ${ }^{* *} p<0.01,{ }^{* *} p<0.05,{ }^{*} p<0.1$. 
Table B7. Effect of overseas educational experience on improved waste collection system.

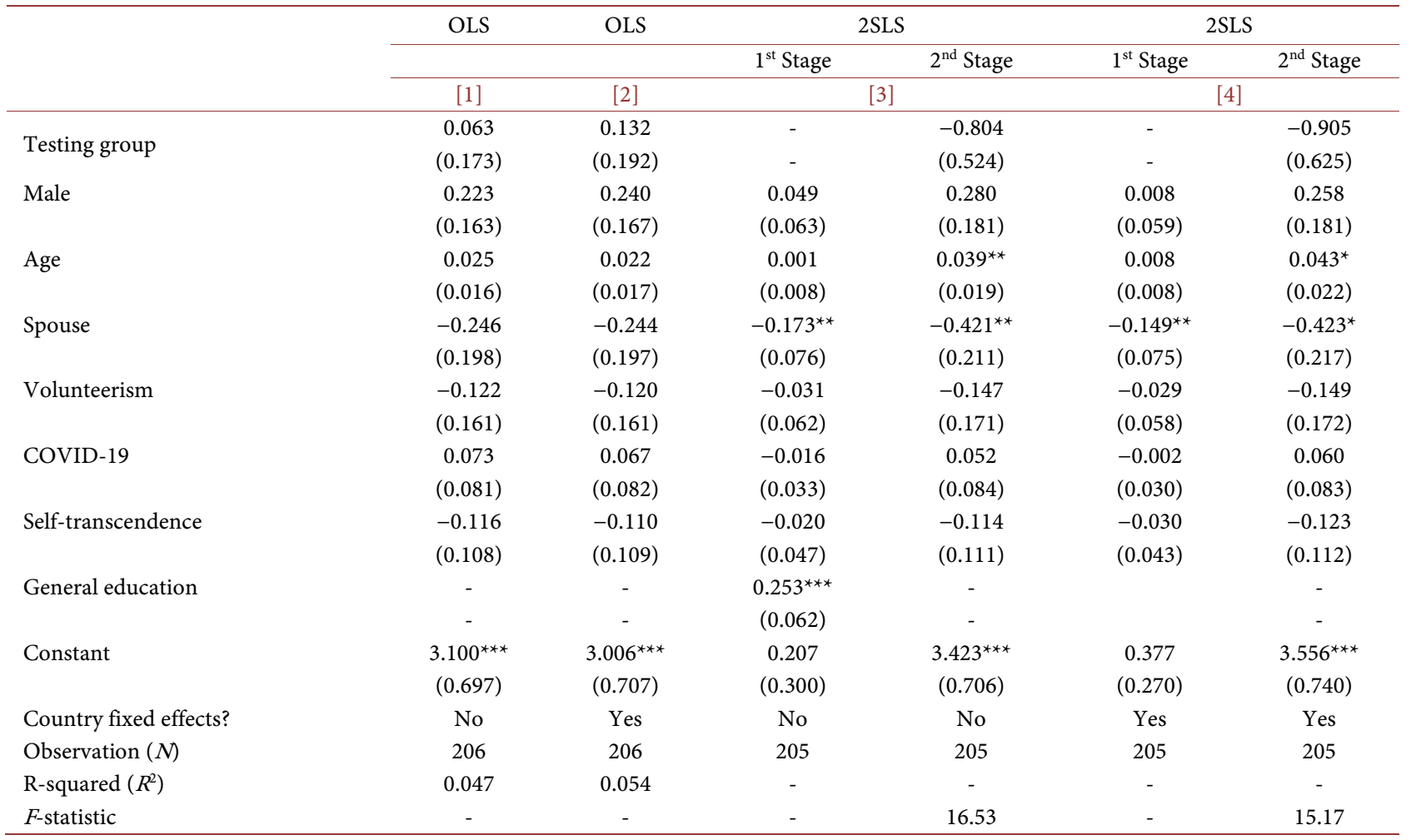

Standard errors are in parentheses. ${ }^{* *} p<0.01,{ }^{* *} p<0.05,{ }^{*} p<0.1$.

Table B8. Effect of overseas education on family members involvement in waste separation.

\begin{tabular}{|c|c|c|c|c|c|c|}
\hline & \multirow[t]{2}{*}{ OLS } & \multirow[t]{2}{*}{ OLS } & \multicolumn{2}{|c|}{$2 S L S$} & \multicolumn{2}{|c|}{ 2SLS } \\
\hline & & & $1^{\text {st }}$ Stage & $2^{\text {nd }}$ Stage & $1^{\text {st }}$ Stage & $2^{\text {nd }}$ Stage \\
\hline & [1] & [2] & & & & \\
\hline \multirow{2}{*}{ Testing group } & -0.256 & $-0.381^{\star \star}$ & - & -0.356 & - & -0.532 \\
\hline & $(0.161)$ & $(0.182)$ & - & $(0.396)$ & - & $(0.473)$ \\
\hline \multirow[t]{2}{*}{ Male } & 0.049 & 0.021 & 0.027 & 0.055 & -0.008 & 0.022 \\
\hline & $(0.158)$ & $(0.159)$ & $(0.062)$ & $(0.156)$ & $(0.060)$ & $(0.156)$ \\
\hline \multirow[t]{2}{*}{ Age } & 0.001 & 0.007 & 0.002 & 0.002 & 0.009 & 0.010 \\
\hline & $(0.016)$ & $(0.018)$ & $(0.008)$ & $(0.017)$ & $(0.008)$ & $(0.020)$ \\
\hline \multirow[t]{2}{*}{ Spouse } & -0.158 & -0.161 & $-0.182^{\star *}$ & -0.183 & $-0.158^{\star *}$ & -0.189 \\
\hline & $(0.206)$ & $(0.210)$ & $(0.075)$ & $(0.214)$ & $(0.074)$ & $(0.218)$ \\
\hline \multirow[t]{2}{*}{ Volunteerism } & $-0.274^{*}$ & $-0.278^{\star}$ & -0.041 & $-0.281^{\star}$ & -0.037 & $-0.284^{\star}$ \\
\hline & $(0.164)$ & $(0.163)$ & $(0.062)$ & $(0.162)$ & $(0.058)$ & $(0.162)$ \\
\hline COVID-19 & 0.014 & 0.025 & -0.021 & 0.010 & -0.005 & 0.024 \\
\hline \multirow[t]{2}{*}{ Self-transcendence } & -0.126 & -0.136 & -0.032 & -0.125 & -0.040 & -0.139 \\
\hline & $(0.115)$ & $(0.116)$ & $(0.046)$ & $(0.113)$ & $(0.042)$ & $(0.113)$ \\
\hline \multirow[t]{2}{*}{ General education } & - & - & $0.267^{\star * *}$ & - & $0.224^{\star * *}$ & - \\
\hline & - & - & $(0.063)$ & - & $-(0.057)$ & - \\
\hline \multirow[t]{2}{*}{ Constant } & $4.134^{\star \star \star}$ & $4.306^{\star * *}$ & $0.241^{\star *}$ & $4.170^{\star \star \star}$ & 0.404 & $4.390^{\star * *}$ \\
\hline & $(0.730)$ & $(0.723)$ & $(0.302)$ & $(0.714)$ & $(0.271)$ & $(0.717)$ \\
\hline Country fixed effects? & No & Yes & No & No & Yes & Yes \\
\hline Observation $(N)$ & 206 & 206 & 205 & 205 & 205 & 205 \\
\hline R-squared $\left(R^{2}\right)$ & 0.037 & 0.052 & - & - & - & - \\
\hline$F$-statistic & - & - & - & 17.59 & - & 15.56 \\
\hline
\end{tabular}

Standard errors are in parentheses. ${ }^{* *} p<0.01,{ }^{* *} p<0.05,{ }^{*} p<0.1$. 
Table B9. Effect of overseas educational experience on waste-separation practice.

\begin{tabular}{|c|c|c|c|c|c|c|c|c|}
\hline & OLS & OLS & \multicolumn{2}{|c|}{ 2SLS } & \multicolumn{2}{|c|}{ 2SLS } & \multirow{2}{*}{$\begin{array}{c}\text { 2SLS } \\
\text { Interaction }\end{array}$} & \multirow{2}{*}{$\begin{array}{c}\text { 2SLS } \\
\text { Interaction }\end{array}$} \\
\hline & & & $1^{\text {st }}$ Stage & $2^{\text {nd }}$ Stage & $1^{\text {st }}$ Stage & $2^{\text {nd }}$ Stage & & \\
\hline & [1] & [2] & \multicolumn{2}{|c|}{ [3] } & \multicolumn{2}{|c|}{ [4] } & [5] & {$[6]$} \\
\hline \multirow{2}{*}{ Testing group } & $0.789^{* * *}$ & 0.147 & - & $1.060^{\star *}$ & - & 0.378 & $0.497^{\star *}$ & 0.088 \\
\hline & $(0.183)$ & (0.194) & - & (0.449) & - & $(0.414)$ & $(0.203)$ & $(0.070)$ \\
\hline \multirow[t]{2}{*}{ Male } & 0.051 & -0.092 & 0.041 & 0.037 & 0.003 & -0.093 & -0.091 & -0.105 \\
\hline & $(0.182)$ & $(0.146)$ & $(0.064)$ & $(0.180)$ & $(0.061)$ & $(0.143)$ & $(0.144)$ & $(0.144)$ \\
\hline \multirow[t]{2}{*}{ Age } & $-0.047^{\star \star}$ & -0.016 & 0.002 & $-0.051^{\star * *}$ & 0.009 & -0.021 & -0.020 & -0.023 \\
\hline & $(0.018)$ & $(0.017)$ & $(0.008)$ & $(0.019)$ & $(0.008)$ & $(0.020)$ & $(0.016)$ & $(0.020)$ \\
\hline \multirow[t]{2}{*}{ Spouse } & 0.193 & 0.210 & $-0.176^{\star *}$ & 0.245 & $-0.147^{\star}$ & 0.245 & 0.259 & 0.261 \\
\hline & $(0.225)$ & $(0.192)$ & $(0.076)$ & $(0.231)$ & $(0.075)$ & $(0.196)$ & 0.194 & $(0.198)$ \\
\hline \multirow[t]{2}{*}{ Volunteerism } & $0.348^{*}$ & $0.345^{\star *}$ & -0.033 & $0.353^{*}$ & -0.028 & $0.349^{* *}$ & - & $0.364^{* *}$ \\
\hline & $(0.206)$ & $(0.168)$ & $(0.063)$ & $(0.204)$ & $(0.059)$ & $(0.167)$ & - & $(0.164)$ \\
\hline \multirow[t]{2}{*}{ COVID-19 } & -0.146 & -0.091 & -0.011 & -0.143 & 0.003 & -0.092 & -0.107 & -0.088 \\
\hline & $(0.090)$ & $(0.079)$ & $(0.034)$ & $(0.089)$ & $(0.030)$ & $(0.077)$ & $(0.077)$ & $(0.075)$ \\
\hline \multirow{2}{*}{ Self-transcendence } & 0.155 & 0.096 & -0.026 & 0.158 & -0.036 & 0.102 & 0.097 & - \\
\hline & $(0.128)$ & $(0.106)$ & $(0.047)$ & $(0.126)$ & $(0.043)$ & $(0.104)$ & $(0.103)$ & - \\
\hline \multirow{2}{*}{ General education } & - & - & $0.247^{\star * *}$ & - & $0.207^{\star * *}$ & - & - & - \\
\hline & - & - & $(0.062)$ & - & $(0.055)$ & - & - & - \\
\hline \multirow[t]{2}{*}{ Constant } & $2.700^{* * *}$ & $3.590^{* * *}$ & 0.239 & $2.589^{\star \star \star}$ & 0.409 & $3.458^{\star * \star}$ & $3.761^{\star \star \star}$ & $3.944^{\star * \star}$ \\
\hline & $(0.780)$ & 0.648 & $(0.302)$ & $(0.754)$ & $(0.271)$ & $(0.604)$ & $(0.609)$ & $(0.432)$ \\
\hline Fixed effects & No & Yes & No & No & Yes & Yes & Yes & Yes \\
\hline Observation & 203 & 203 & 203 & 203 & 203 & 203 & 203 & 203 \\
\hline$R$-squared & 0.149 & 0.403 & - & - & - & - & - & - \\
\hline$F$-statistic & - & - & - & 15.74 & - & 14.27 & 156.42 & 10.65 \\
\hline \multirow{2}{*}{ Hansen J statistic } & \multirow{2}{*}{\multicolumn{6}{|c|}{$\begin{array}{l}\text { (Overidentification test of all instruments): } \\
\text { Chi-sq (1) P-val = }\end{array}$}} & 0.077 & 0.156 \\
\hline & & & & & & & 0.781 & 0.693 \\
\hline
\end{tabular}

OLS: Ordinary Least Square. Standard errors are in parentheses. ${ }^{* *} p<0.01,{ }^{* *} p<0.05,{ }^{*} p<0.1$.

Table B10. Effect of overseas educational experience on waste-separation practice.

\begin{tabular}{|c|c|c|c|c|c|c|}
\hline & \multirow[t]{2}{*}{ OLS } & \multirow[t]{2}{*}{ OLS } & \multicolumn{2}{|c|}{ 2SLS } & \multicolumn{2}{|c|}{ 2SLS } \\
\hline & & & $1^{\text {st }}$ Stage & $2^{\text {nd }}$ Stage & $1^{\text {st }}$ Stage & $2^{\text {nd }}$ Stage \\
\hline & [1] & [2] & & & & \\
\hline \multirow{2}{*}{ Testing group } & -0.118 & -0.041 & - & -0.451 & - & -0.440 \\
\hline & $(0.117)$ & $(0.129)$ & - & $(0.363)$ & - & $(0.434)$ \\
\hline \multirow[t]{2}{*}{ Male } & $-0.256^{\star *}$ & $-0.238^{\star *}$ & 0.040 & $-0.244^{\star *}$ & 0.001 & $-0.241^{\star *}$ \\
\hline & $(0.117)$ & $(0.118)$ & $(0.063)$ & $(0.118)$ & $(0.060)$ & $(0.118)$ \\
\hline \multirow[t]{2}{*}{ Age } & -0.001 & -0.005 & 0.001 & 0.004 & 0.008 & 0.003 \\
\hline & $(0.011)$ & $(0.011)$ & $(0.008)$ & $(0.013)$ & $(0.008)$ & $(0.015)$ \\
\hline \multirow[t]{2}{*}{ Spouse } & 0.147 & 0.149 & $-0.185^{\star *}$ & 0.093 & $-0.159^{* *}$ & 0.093 \\
\hline & $(0.145)$ & $(0.145)$ & $(0.075)$ & $(0.160)$ & $(0.074)$ & $(0.160)$ \\
\hline \multirow[t]{2}{*}{ Volunteerism } & 0.127 & 0.129 & -0.035 & 0.132 & -0.031 & 0.132 \\
\hline & $(0.136)$ & $(0.136)$ & $(0.062)$ & $(0.134)$ & $(0.059)$ & $(0.134)$ \\
\hline \multirow[t]{2}{*}{ COVID-19 } & $-0.125^{\star *}$ & $-0.131^{* *}$ & -0.011 & $-0.124^{\star *}$ & 0.003 & $-0.125^{*}$ \\
\hline & $(0.063)$ & $(0.064)$ & $(0.034)$ & $(0.062)$ & $(0.030)$ & $(0.064)$ \\
\hline \multirow[t]{2}{*}{ Self-transcendence } & $0.168^{\star}$ & $0.174^{\star}$ & -0.027 & $0.159^{*}$ & -0.036 & $0.160^{*}$ \\
\hline & $(0.090)$ & $(0.090)$ & $(0.047)$ & $(0.089)$ & $(0.043)$ & $(0.089)$ \\
\hline \multirow{2}{*}{ General education } & - & - & $0.254^{* * *}$ & - & $0.215^{* * *}$ & - \\
\hline & - & - & $(0.062)$ & - & $(0.054)$ & - \\
\hline \multirow[t]{2}{*}{ Constant } & $2.868^{* * *}$ & $2.763^{* * *}$ & 0.241 & $3.031^{* * *}$ & 0.408 & $3.017^{* * *}$ \\
\hline & $(0.575)$ & $(0.588)$ & $(0.301)$ & $(0.569)$ & $(0.271)$ & $(0.597)$ \\
\hline Country fixed effects? & No & Yes & No & No & Yes & Yes \\
\hline Observation $(N)$ & 206 & 206 & 205 & 205 & 205 & 205 \\
\hline R-squared $\left(R^{2}\right)$ & 0.071 & 0.080 & - & - & - & - \\
\hline$F$-statistic & - & - & - & 16.89 & - & 15.59 \\
\hline
\end{tabular}

Standard errors are in parentheses. ${ }^{* *} p<0.01,{ }^{* *} p<0.05,{ }^{*} p<0.1$. 
Table B11. I plan to compost my garbage separated.

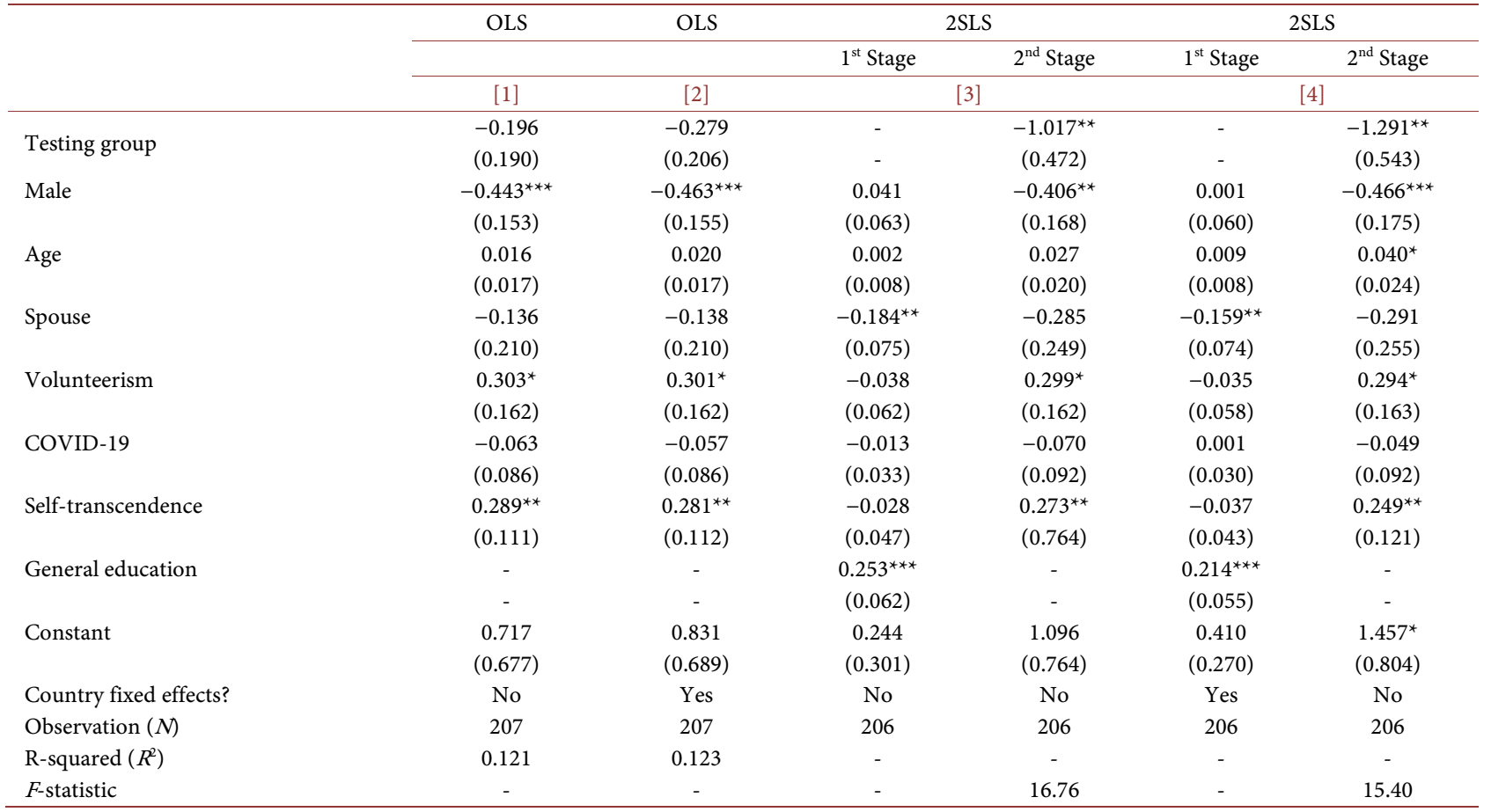

Standard errors are in parentheses. ${ }^{* * *} p<0.01,{ }^{* *} p<0.05,{ }^{*} p<0.1$.

Table B12. Effect of overseas educational experience on shopping-bag usage.

\begin{tabular}{|c|c|c|c|c|c|c|c|}
\hline & \multirow[t]{2}{*}{ OLS } & \multirow[t]{2}{*}{ OLS } & \multicolumn{2}{|c|}{ 2SLS } & \multicolumn{2}{|c|}{ 2SLS } & \multirow{2}{*}{$\begin{array}{c}\text { Ordered } \\
\text { Probit }\end{array}$} \\
\hline & & & $1^{\text {st }}$ Stage & $2^{\text {nd }}$ Stage & $1^{\text {st }}$ Stage & $2^{\text {nd }}$ Stage & \\
\hline & [1] & {$[2]$} & \multicolumn{2}{|c|}{ [3] } & \multicolumn{2}{|c|}{$[4]$} & {$[5]$} \\
\hline \multirow{2}{*}{ Testing group } & $0.696^{* * *}$ & $0.579^{* * *}$ & - & $0.922^{\star *}$ & - & $0.834^{*}$ & $0.651^{* * *}$ \\
\hline & $(0.163)$ & $(0.170)$ & - & $(0.371)$ & - & $(0.429)$ & $(0.199)$ \\
\hline \multirow[t]{2}{*}{ Male } & $-0.467^{\star * *}$ & $-0.494^{\star * *}$ & 0.428 & $-0.488^{* * *}$ & 0.003 & $-0.507^{\star * *}$ & $-0.662^{* * *}$ \\
\hline & $(0.140)$ & $(0.136)$ & $(0.063)$ & $(0.139)$ & $(0.050)$ & $(0.135)$ & $(0.176)$ \\
\hline Age & $(0.014)$ & $(0.014)$ & $(0.008)$ & $(0.015)$ & $(0.008)$ & $(0.016)$ & $(0.017)$ \\
\hline \multirow[t]{2}{*}{ Spouse } & 0.100 & 0.099 & $-0.181^{\star \star}$ & 0.167 & $-0.154^{\star *}$ & 0.167 & 0.045 \\
\hline & $(0.173)$ & $(0.169)$ & $(0.076)$ & $(0.187)$ & $(0.075)$ & $(0.184)$ & $(0.207)$ \\
\hline \multirow[t]{2}{*}{ Volunteerism } & 0.070 & 0.066 & -0.036 & 0.096 & -0.032 & 0.095 & 0.067 \\
\hline & $(0.139)$ & $(0.137)$ & $(0.062)$ & $(0.138)$ & $(0.059)$ & $(0.135)$ & $(0.167)$ \\
\hline \multirow[t]{2}{*}{ COVID-19 } & -0.096 & -0.086 & -0.012 & -0.083 & 0.003 & -0.076 & -0.118 \\
\hline & $(0.075)$ & $(0.77)$ & $(0.034)$ & $(0.075)$ & $(0.031)$ & $(0.076)$ & $(0.093)$ \\
\hline Self-transcendence & $(0.105)$ & $(0.103)$ & $(0.047)$ & $(0.105)$ & $(0.051)$ & $(0.104)$ & $(0.133)$ \\
\hline \multirow{2}{*}{ General education } & - & - & $0.254^{\star \star \star *}$ & - & $0.215^{\star \star *}$ & - & - \\
\hline & - & - & $(0.062)$ & - & $(0.054)$ & - & - \\
\hline \multirow[t]{2}{*}{ Constant } & $1.477^{\star \star}$ & $1.639^{* * *}$ & 0.250 & $1.414^{\star \star}$ & 0.420 & $1.534^{\star \star}$ & - \\
\hline & $(0.617)$ & $(0.602)$ & $(0.302)$ & $(0.638)$ & $(0.271)$ & $(0.658)$ & - \\
\hline Country fixed effects? & No & Yes & No & No & Yes & Yes & Yes \\
\hline Observation $(N)$ & 205 & 205 & 204 & 204 & 204 & 204 & 205 \\
\hline R-squared $\left(R^{2}\right)$ & 0.220 & 0.234 & - & - & - & - & - \\
\hline$F$-statistic & - & - & - & 16.88 & - & 15.58 & - \\
\hline /cut 1 & - & - & - & - & - & - & -0.860 \\
\hline /cut 2 & - & - & - & - & - & - & -0.127 \\
\hline /cut3 & - & - & - & - & - & - & 0.872 \\
\hline / cut4 & - & - & - & - & - & - & 2.347 \\
\hline
\end{tabular}

Standard errors are in parentheses. ${ }^{* * *} p<0.01,{ }^{* *} p<0.05,{ }^{*} p<0.1$. 
Table B13. Effect of overseas educational experience on shopping-bag usage.

\begin{tabular}{|c|c|c|c|c|c|c|c|c|c|c|}
\hline & Self-transcendence & $\mathrm{X} 8$ & X9 & $\mathrm{X} 11$ & $\mathrm{X} 13$ & $\mathrm{X} 14$ & $\mathrm{X} 15$ & Male & Volunteerism & $\begin{array}{c}\text { COVID- } \\
19\end{array}$ \\
\hline Self-transcendence & 1 & - & - & - & - & - & - & - & - & - \\
\hline $\mathrm{X} 8$ & $-0.16^{* *}$ & 1 & - & - & - & - & - & - & - & - \\
\hline X9 & $-0.24^{\star * \star}$ & $0.40^{* * *}$ & 1 & - & - & - & - & - & - & - \\
\hline $\mathrm{X} 11$ & $-0.13^{\star *}$ & $0.25^{\star * *}$ & 0.12 & 1 & - & - & - & - & - & - \\
\hline $\mathrm{X} 13$ & $0.22^{\star * *}$ & $-0.16^{* *}$ & -0.10 & $-0.17^{\star *}$ & 1 & - & - & - & - & - \\
\hline $\mathrm{X} 14$ & $0.14^{* *}$ & $-0.17^{\star *}$ & -0.06 & -0.13 & $0.30^{* * *}$ & 1 & - & - & - & - \\
\hline $\mathrm{X} 15$ & $0.18^{\star * *}$ & -0.06 & $-0.18^{\star * *}$ & -0.04 & $0.33^{* * *}$ & $0.25^{\star * *}$ & 1 & - & - & - \\
\hline Male & $-0.23^{* * *}$ & -0.11 & -0.07 & -0.01 & $-0.26^{\star * *}$ & $-0.17^{\star *}$ & -0.03 & 1 & - & - \\
\hline Volunteerism & $0.15^{\star *}$ & -0.02 & -0.06 & -0.01 & $0.21^{\star * *}$ & 0.11 & 0.05 & $-0.18^{\star * *}$ & 1 & - \\
\hline COVID-19 & $0.18^{* * *}$ & 0.06 & $0.16^{* *}$ & 0.01 & -0.02 & -0.05 & -0.07 & -0.07 & 0.03 & 1 \\
\hline
\end{tabular}

Note: X8: Is waste separation difficult? X9: Don't you have time for waste separation? X11: Is improved waste collection necessary? X13: Do you intend to compost the waste separated? X14: Do you intend to sell the wastes separated? X15: Do you intend to separate waste into organic and non-organic? ${ }^{\star} p<0.10,{ }^{\star *} p<0.05,{ }^{\star * *} p<0.01$.

Table B14. I plan to separate my garbage into organic and non-organic.

\begin{tabular}{|c|c|c|c|c|c|c|}
\hline & OLS & OLS & & & & \\
\hline & & & $1^{\text {st }}$ Stage & $2^{\text {nd }}$ Stage & $1^{\text {st }}$ Stage & $2^{\text {nd }}$ Stage \\
\hline & {$[1]$} & {$[2]$} & & & & \\
\hline & -0.047 & -0.103 & - & -0.055 & - & -0.122 \\
\hline 1 esting group & $(0.114)$ & $(0.126)$ & - & $(0.270)$ & - & $(0.312)$ \\
\hline Male & 0.007 & -0.007 & 0.040 & 0.004 & 0.001 & -0.011 \\
\hline & $(0.105)$ & $(0.108)$ & $(0.063)$ & $(0.104)$ & $(0.060)$ & $(0.105)$ \\
\hline Age & 0.005 & 0.007 & 0.001 & 0.004 & 0.008 & 0.007 \\
\hline & $(0.011)$ & $(0.011)$ & $(0.008)$ & $(0.012)$ & $(0.008)$ & $(0.012)$ \\
\hline Spouse & 0.024 & 0.023 & $-0.185^{\star \star}$ & 0.031 & $-0.159^{\star \star}$ & 0.030 \\
\hline & $(0.131)$ & $(0.131)$ & $(0.075)$ & $(0.139)$ & $(0.074)$ & $(0.138)$ \\
\hline Volunteerism & 0.030 & 0.029 & -0.035 & 0.039 & -0.031 & 0.038 \\
\hline & $(0.106)$ & $(0.106)$ & $(0.062)$ & $(0.104)$ & $(0.059)$ & $(0.104)$ \\
\hline COVID-19 & -0.091 & -0.086 & -0.011 & -0.087 & 0.003 & -0.082 \\
\hline & $(0.060)$ & $(0.061)$ & $(0.034)$ & $(0.060)$ & $(0.030)$ & $(0.060)$ \\
\hline Self-transcendence & $0.247^{\star *}$ & $0.242^{\star *}$ & -0.027 & $0.243^{\star *}$ & -0.036 & $0.237^{\star *}$ \\
\hline & $(0.097)$ & $(0.098)$ & $(0.047)$ & $(0.096)$ & $(0.043)$ & $(0.645)$ \\
\hline General education & - & - & $0.254^{\star \star *}$ & - & $0.215^{\star * *}$ & - \\
\hline & - & - & $(0.062)$ & - & $(0.054)$ & - \\
\hline Constant & $2.125^{\star * *}$ & $2.202^{\star * *}$ & 0.241 & $2.143^{* * *}$ & 0.408 & $2.232^{\star * *}$ \\
\hline & $(0.602)$ & $(0.617)$ & $(0.301)$ & $(0.612)$ & $(0.271)$ & $(0.645)$ \\
\hline Country fixed effects? & No & Yes & No & No & Yes & Yes \\
\hline Observation $(N)$ & 206 & 206 & 205 & 205 & 205 & 205 \\
\hline $\mathrm{R}$-squared $\left(R^{2}\right)$ & 0.052 & 0.057 & - & - & - & - \\
\hline$F$-statistic & - & - & - & 16.89 & - & 15.59 \\
\hline
\end{tabular}

Standard errors are in parentheses. ${ }^{\star * *} p<0.01,{ }^{* *} p<0.05,{ }^{*} p<0.1$. 
Table B15. Average marginal effects after ordered probit.

\begin{tabular}{ccccccc}
\hline & \multicolumn{3}{c}{ Marginal Effects } \\
\cline { 2 - 6 } & Never & Rarely & Sometimes & Often & Always \\
\cline { 2 - 6 } & {$[1]$} & {$[2]$} & {$[3]$} & {$[4]$} & {$[5]$} & $0.143^{* * *}$ \\
Testing group & $-0.028^{* *}$ & $-0.072^{* * *}$ & $-0.141^{* * *}$ & $0.099^{* *}$ & $(0.041)$ & $(0.043)$ \\
Observations $(N)$ & $(0.014)$ & $(0.027)$ & $(0.047)$ & 207 & 207 & 207 \\
\hline
\end{tabular}

Standard errors are in parentheses. ${ }^{* *} p<0.01,{ }^{* *} p<0.05,{ }^{\star} p<0.1$.

\section{Interaction Effect:}

To make sure if people engaged in social and environmental affairs (volunteerism) will practice waste separation regardless of how inconvenient the waste management system is, I interacted the dummy variable of overseas educational experience with volunteerism variable (regression 5, Table B9). The result is robust to the claim with coefficient $(\beta=0.497, p<0.05)$ with $F$-statistic $=156.42$. On contrary, the interaction effect between the coefficient of overseas educational experience and self-transcendence is statistically insignificant $(\beta=0.088, p>0.05)$ with small $F$-statistic $=10.65$ (regression 6, Table B9).

\section{Average Marginal Effects:}

The probability of sorting garbage among the fellows is statistically insignificant upon their arrival in Cambodia (regression 4, Table B9). However, the probability of using shopping bag is statistically significant (regression $4 \& 5$, Table B12) even after their arrival at their home country. The coefficient of average marginal effect is all negative in the first bottom three categories: never, rarely and sometimes but positive for often and always (Table B15). Therefore, experiencing overseas education decreases the probability of not using shopping bag but increases the probability of using it by approximately $11 \%$ and $16 \%$ for category "often" and "always" respectively. 